\title{
The current status of coral reefs and their vulnerability to climate change and multiple human stresses in the Comoros Archipelago, Western Indian Ocean
}

Cowburn, B. ${ }^{1^{*}}$, Samoilys, M.A. ${ }^{1}$ and Obura, D. ${ }^{1}$

1. CORDIO East Africa, 9 Kibaki Flats, Kenyatta Beach, Bamburi Beach, P.O.BOX 10135 Mombasa 80101, Kenya

* Corresponding author: benjamindcowburn@ gmail.com

Keywords: Climate change, Coral bleaching, Resilience, Artisanal fisheries, Pollution 


\begin{abstract}
Coral bleaching and various human stressors have degraded the coral reefs of the Comoros Archipelago in the past 40 years and rising atmospheric $\mathrm{CO}_{2}$ levels are predicted to further impact marine habitats. The condition of reefs in the Comoros is poorly known; using SCUBA based methods we surveyed reef condition and resilience to bleaching at sites in Grande Comore and Mohéli in 2010 and 2016. The condition of reefs was highly variable, with a range in live coral cover between $6 \%$ and $60 \%$ and target fishery species biomass between 20 and $500 \mathrm{~kg}$ per ha. The vulnerability assessment of reefs to future coral bleaching and their exposure to fishing, soil erosion and river pollution in Mohéli Marine Park found that offshore sites around the islets south of the island were least likely to be impacted by these negative pressures. The high variability in both reef condition and vulnerability across reefs in the Park lends itself to spatially explicit conservation actions. However, it is noteworthy that climate impacts to date appear moderate and that local human pressures are not having a major impact on components of reef health and recovery, suggesting these reefs are relatively resilient to the current anthropogenic stresses that they are experiencing.
\end{abstract}

\title{
Résumé
}

Le blanchiment du corail et les diverses pressions humaines ont dégradé les récifs coralliens de l'archipel des Comores au cours des 40 dernières années et il est prévu que l'augmentation de la concentration de $\mathrm{CO}_{2}$ dans l'atmosphère va nuire davantage aux habitats marins. La condition des récifs aux Comores est peu connue; à l'aide de méthodes SCUBA, nous avons suivi la condition des récifs et leur résilience au blanchiment du corail dans des sites en Grande Comore et Mohéli en 2010 et 2016. La condition des récifs était très variable, avec une gamme de couverture de corail entre $6 \%$ et $60 \%$ et une biomasse des poisson-cibles à la pêche entre $20-500 \mathrm{~kg}$ per ha. L'évaluation de la vulnérabilité de récifs au blanchiment du corail et leur exposition à la pêche, à l'érosion des sols et à la pollution fluviale dans le Parc National de Mohéli, a trouvé que les sites au large, près des îlots au Sud de l'île, étaient le moins susceptibles d'être affectés par ces pressions négatives. La grande variabilité dans les conditions des récifs et leur vulnérabilité aux pressions anthropogéniques, se prêtent à des mesures de conservation spatialement explicites. Cependant, nous avons trouvé que les impacts climatiques sont modérés et que les pressions humaines locales n'affectent pas beaucoup les processus critiques à la santé des récifs et à leur reprise des stress aigus, ce qui suggère que ces récifs sont résilients aux stress anthropogéniques auxquels ils sont soumis. 


\section{Introduction}

Mass coral bleaching and mortality have impacted coral reefs in nearly every part of the world including many sites in the western Indian Ocean (WIO), especially during the extreme El-Niño Southern-Oscillation (ENSO) events in 1997-1998 and 20152016 (Wilkinson 2008, Ateweberhan et al 2011, Heron et al. 2016, Obura et al. 2017a). The Northern Mozambique Channel (NMC), which comprises northern Madagascar, northern Mozambique, southern Tanzania and the Comoros is an area of global biodiversity importance (Obura 2012) but is also threatened by climate and local human pressures (Obura et al. 2012, 2015, McClanahan et al. 2014). Further, the coastal peoples of these countries are intimately dependent on marine resources and habitats for their livelihoods (Obura et al 2017b).

The islands of the Comoros Archipelago are geologically recent, formed by volcanic hotspot activity which began approximately 10 million years ago (Audru et al. 2010). These four islands covering $2,230 \mathrm{~km}^{2}$, have a combined coastline of $340 \mathrm{~km}$ which is largely fringed by coral reefs. The Republic of Comoros (excluding Mayotte, which is a département of France) support a population of $\sim 700,000$ with an annual growth rate of $\sim 3 \%$. The islands have one of the lowest human development index (HDI) in the WIO and economic development is low (UNDP 2013, Obura et al. 2017b). Grande Comore with the capital city Moroni has the largest population $(300,000)$, whereas an estimated 45,000 people live on Mohéli, making it the least densely populated island in the archipelago. Direct and indirect human pressures on reefs in Comoros include fishing, pollution and sewage from towns, sand mining, and soil erosion as a result of deforestation and agriculture (Freed and Granek 2014, Audru et al. 2010). 
Future management of coral reefs requires a better understanding of climate vulnerability to develop appropriate strategies that will help to address both human and climate impacts on marine and coastal resources and local communities (Maynard et al. 2010, Anthony et al. 2015). A vulnerability analysis of a threat to a coral reef requires knowledge of the reef's exposure to the threat, the sensitivity of the reef and its ability to recover from acute stress (Cinner et al. 2012, Harris et al. 2017). The most important factors for triggering coral bleaching are temperature and light (Coles and Jokiel 1978). Physical factors that reduce coral's exposure to temperature and light during a bleaching event include depth, shade from sunlight, high wave exposure and cool upwelling (West and Salm 2003, Obura 2005). The reef's sensitivity to bleaching is determined by the composition of the coral community, with certain genera (Acropora, Monitpora, Seriatopora, Pocillopora and branching Porites) being consistently more sensitive to bleaching than others (Loya et al. 2001, McClanahan et al. 2007). Factors important for reef recovery include low algal competition with corals, high abundance of herbivorous and detritivorous fishes, high coral recruitment and suitable substrate for new coral growth (Obura 2005, Hughes et al. 2007, McClanahan et al. 2012, Bellwood et al. 2014). Local human impacts can reduce reef recovery potential (Fabricius 2005, Mumby et al. 2006) hence local stressors of pollution, fishing and coastal erosion are considered alongside the climate vulnerability assessment.

The Worldwide Fund for Nature (WWF) have spearheaded the 'Climate Adaptation Methodology for Protected Areas' (CAMPA) approach in protected areas around the world (Belokurov et al. 2016). In this study the climate vulnerability of reefs in the Parc National de Mohéli (PNM) was investigated and represents the second 
application of this method in an MPA in the NMC, after the assessment carried out by Gough (2012) in Nosy Hara, Madagascar. We quantify the condition of the reefs in Grande Comore and Mohéli in 2010 and 2016, calculate the vulnerability to climate change and human stressors in Mohéli and compare these reefs with other countries in the WIO.

\section{Methods}

\section{Sites and survey periods}

In 2010 six sites were surveyed in Grande Comore and 4 sites in Mohéli and in 2016 only Mohéli was visited, where data were collected from 10 sites (Table S1). Most sites were $\sim 10 \mathrm{~m}$ on reef slopes, with the exception of Ferenga $(18 \mathrm{~m})$, Nioumachoua (5m) and Nioumachoua Flat $(1 \mathrm{~m})$. In Grande Comore the only reef geomorphology (sensu Andréfouët et al. 2006) is Ocean-Exposed Fringing-Reefs (OEFR), with coral communities on underlying basalt bed-rock or narrow reef platforms along the coastline of this young volcanic island. In Mohéli the reef structures surrounding the island are more developed, with several reef geomorphologies (Table S1) and reefassociated habitats, such as seagrass beds and mangroves. Offshore from the central part of PNM a shallow $(<50 \mathrm{~m})$ plateau extends beyond the main island to $10 \mathrm{~km}$ offshore, on which are several smalluninhabited islands (islets). Three reef morphologies were observed at sites in Mohéli including Ocean-Exposed Fringing Reef (OEFR), Intra-Seas Fringing Reef (ISFR) and a Coastal Patch Reef (CPR) at Sambia.

\section{Survey methods}


Data were collected on the coral, fish, algae and benthic structure of the reef. Benthic cover was recorded using photo-quadrats. In 2010 photo-quadrats were recorded from a height of $\sim 70 \mathrm{~cm}$ from the substrate, in clusters of 5-6 adjacent to transects with 20 24 photos per site. In 2016 fifteen $1 \mathrm{~m}^{2}$ quadrats were photographed. Cover was analysed with Coral Point Count with Excel extensions (CPCe) (Kohler and Gill 2006) using a grid of 25 points per image. Major benthic categories included: hard coral, soft coral, recently killed coral, sponge, macroalgae, turf algae, bare substrate and loose sediment and in 2016 the frond length of turf and macroalgae was measured.

Fish were counted in five $50 \times 5 \mathrm{~m}\left(250 \mathrm{~m}^{2}\right)$ belt transects per site (Samoilys and Carlos 2000). In 2016 all species from 11 important reef fish families were included: Acanthuridae, Chaetodontidae, Ephippidae, Epinephelidae, Haemulidae, Kyphosidae, Lethrinidae, Lutjanidae, Pomacanthidae, Scarinae (Labridae), Siganidae (Supplementary Table S2). In 2010 species from 8 families were counted, excluding Ephippidae, Haemulidae and Kyphosidae. Each fish $(>5 \mathrm{~cm}$ TL) was identified to species and assigned to trophic groups (Green and Bellwood 2009, Obura et al. 2011) with its total length estimated to the nearest $5 \mathrm{~cm}$. The fish observer also recorded the presence of each unique species seen from 19 families during a 75-minute search period around the site (Obura et al. 2011). The approximate area of reef searched at each site during this period was $\sim 7000 \mathrm{~m}^{2}(350 \mathrm{~m} \times 20 \mathrm{~m})$.

Adult coral colonies $(>10 \mathrm{~cm})$ were assessed in belt transects, whereas juvenile colonies $(<10 \mathrm{~cm})$ were assessed in quadrats (Obura and Grimsditch 2009). In 2010 belt transects varied in size ( $1 \mathrm{~m}$ wide and 11 to $25 \mathrm{~m}$ long) and juvenile corals were 
sampled in $1 \mathrm{~m}^{2}$ quadrats placed within the belts (2-5 per site). In 2016 five $1 \mathrm{~m}$ x $10 \mathrm{~m}$ belt transects were sampled per site, with three $1 \mathrm{~m}^{2}$ quadrats placed at regular intervals along each transect (15 in total). In 2010 colony size was binned in varyingwidth size classes (Obura and Grimsditch 2009), while in 2016 length was estimated to the nearest $5 \mathrm{~cm}$. The condition of colonies with obvious damage (bleaching, disease or mortality within the past 6 months) was also recorded. Overall coral genus richness (presence/absence) was recorded in random swims across the entire sites.

\section{Reef condition and vulnerability to coral bleaching}

Reef condition was defined using the indicators: coral cover, coral genus richness, biomass of fishery target species and the coral fish diversity index (CFDI) (Table 1). Coral cover was obtained from the analysis of photoquadrats and coral genus richness was obtained from coral belt transects. Reef fish taxa targeted by artisanal fishing in PNM consist of Lutjanidae, Lethrinidae, Epinephelidae and Haemulidae (Freed and Granek 2014). CFDI is a biodiversity index that estimates species richness based on six specious reef fish families (Chaetodontidae, Pomacanthidae, Pomacentridae, Labridae, Scarinae (Labridae) and Acanthuridae, Allen and Werner 2002).

Equation 1. Vulnerability equation sensu Cinner et al. 2012

$$
\operatorname{Vulnerability}(V)=\frac{[\operatorname{Exposure}(E)+\operatorname{Sensitivity}(S)]}{\text { Recovery }(R)}
$$

Vulnerability to bleaching was calculated for sites in Mohéli by measuring a range of factors (Obura and Grimsditch 2009, McClanahan et al. 2012) that reduce bleaching exposure (E), bleaching sensitivity (S) and improve the recovery potential (R) 
(Equation 1). Bleaching exposure is reduced by high wave exposure, physical shading from sunlight, proximity to deep water $(<100 \mathrm{~m})$ and depth. The dominant wind and wave direction in the Comoros is from the South-East (Schott et al. 2009), therefore wave exposure of a site was determined by the number of degrees that face open ocean (i.e. not sheltered by headlands or islands) between the compass angles $90^{\circ}$ (E) $180^{\circ}(\mathrm{S})$. Shading was visually estimated as the number of hours during the day that the sites were physically shaded from direct sunlight by the land (i.e. mountains or cliffs). Proximity to deep water was measured as the linear distance between the site and the nearest $100 \mathrm{~m}$ isobath.

Bleaching sensitivity (S) was described by the percentage of coral tissue area from thermally sensitive genera (Acropora, Montipora, Pocillopora, Seriatopora and branching Porites). Coral tissue area was estimated from the equation for ellipses using the long axis of coral colonies as the diameter. Recovery potential (R) from an acute bleaching disturbance, was defined using six indicators (Table 1); turf algal volume $\left(\mathrm{cm}^{3}\right.$ per $\left.\mathrm{m}^{2}\right)$, macroalgal volume $\left(\mathrm{cm}^{3}\right.$ per $\left.\mathrm{m}^{2}\right)$, coral recruit abundance (recruits per $\mathrm{m}^{2}$ ), herbivore-detritivore fish abundance (individuals per ha), solid substrate $(\%)$, and loose sediment (\%) covering solid surfaces. Algal volume was calculated from quadrat data, where the area covered by algae (in $\mathrm{cm}^{2}$ from photoquadrats), is multiplied by the average height of the algae $(\mathrm{cm})$. Coral recruit density was defined as the abundance of recruits counted in each quadrat divided by the area of suitable substrate (\% cover of bare rock, recently killed corals and turf algae). Herbivore-detritivore fish abundance was calculated as the sum of all fish counted in trophic groups: browsers, grazers, grazer-detritivores, detritivores, scrapers and excavators (Table S2). Solid substrate refers to any benthic category from 
photoquadrats that is not sand or loose rubble. Loose sediment was estimated as the proportion of solid substrate with mobile sand or mud on its surface.

Each exposure factor (e) and sensitivity factor (s) was converted into a relative scale from 1 (best) to 5 (worst) (Table 2). The range in values for each indicator from sites in PNM was divided with equal breaks for each score (i.e. range/5). For example, coral cover had a range of $6-63 \%(57 \%)$, hence each score break is $11 \%(57 / 5)$ apart. For recovery factors (r) the scoring is inverted, so that 1 is the worst score and 5 is the best. Indicators were combined using Equation 2 to give the values (E), (S) and (R) used for site vulnerability (Equation 1).

Equation 2. Calculation of each component score (Exposure 'E', Sensitivity 'S', Recovery ' $R$ ' and Human ' $H$ ') from individual indicator scores ('e', 's', 'r' and ' $h$ ')

$$
\text { Component Score }(E, S, R \text { or } H)=\frac{\text { sum of indicator scores }\left(i_{1}+i_{2} \ldots i_{n}\right)}{\text { number of indicators }\left(i_{n}\right)}
$$

\section{Climate and human pressure in PNM}

Climate pressure in PNM was assessed using records of historical coral bleaching and by examining the sea surface temperature (SST) trends from 1985-2016. Bleaching records were gathered from literature searches and Coastal Oceans Research and Development - Indian Ocean (CORDIO)'s bleaching alerts (http://cordioea.net/bleaching resilience). SSTs for PNM were derived from the Advanced Very High Resolution Radiometer (AVHRR) pixel nearest to PNM centred at $12.375^{\circ} \mathrm{S}, 43.625^{\circ} \mathrm{E}$. The data were accessed from http://las.incois.gov.in/las. The maximum monthly mean (MMM) was calculated as the mean SST during the 
warmest month of the years 1985-1990 and 1993 and the coral bleaching threshold for PNM was assumed to be $\mathrm{MMM}+1^{\circ} \mathrm{C}$ (Liu et al. 2003). The severity of thermal stress was measured using 'Degree Heating Weeks' (DHWs), where $1 \mathrm{DHW}$ is a $+1^{\circ} \mathrm{C}$ anomaly above MMM lasting for 1 week.

Human threats were identified during a participatory mapping exercise that took place with PNM staff, volunteers and eco-guards. From these discussions, three main human threats affecting reefs in PNM were considered: fishing pressure, river pollution and sedimentation from soil erosion. A metric of fishing pressure at each site was calculated as the population of nearby village(s) divided by the distance from the site to the village(s) (Cinner et al. 2016). A metric of river pollution was calculated in a similar way, by dividing the number of people living near the river by the distance from the polluted river mouth to the site (West and van Woesik 2001). Soil erosion was estimated using the proportion of primary rainforest (PF), agroforestry matrix (AF) and open land (OL) in the 6 main watersheds along the coast of PNM (Yuan et al. 2015). The boundaries of watersheds were overlaid onto a habitat map of Mohéli (Hawlitschek et al. 2001) and the proportion of these three land-uses was visually estimated for each watershed (Yuan et al. 2015). A score of soil erosion for each watershed was calculated by weighting the proportion of each land-use from 1 for PF (best) to 3 for OL (worst) (Equation 3). The influence of erosion at the site was calculated as the erosion score divided by the distance from the site to the nearest coastline. 
Equation 3. Soil erosion score for watersheds based on the proportion (\%) of primary forest (PF), agro-forestry matrix (AF) and open land (OL) and a weighting of 1 (best) to 3 (worst)

$$
\text { Watershed erosion score }=\% P F \times 1+\% A F \times 2+\% O L \times 3
$$

Correlations between benthic indicators (hard coral, macroalgae, turf algae and recruit abundance), fish indicators (target fishery species biomass and length; and herbdetritivore abundance) and human pressure indicators (fishing pressure, river pollution and soil erosion) were investigated. The indicators macroalgae, fish pressure and river pollution were not normally distributed and hence correlation with these variables was conducted using Spearman's rank ( $\mathrm{Sr})$. Comparisons of other variables used linear models $(\mathrm{lm})$.

\section{Results}

\section{Reef condition}

Coral cover $(\%)$ varied greatly from a minimum of $6.0 \%$ in Itsamia to a maximum of 65.0\% in Mereni (2010 survey) and 62.5\% Nioumachoua (Fig. 2). Sites investigated in 2010 had a mean coral cover of $39.0 \%(\mathrm{SE} \pm 6.7)$ and a dominance of the family Acroporidae, which made up an average of 52.0\% (SE \pm 10.6$)$ of the total coral cover. In 2016 the mean site coral cover was $29.0 \%$ ( $\mathrm{SE} \pm 5.3$ ), of which a mean of $29.0 \%$ (SE \pm 6.3$)$ was Acroporidae cover and 38\% (SE \pm 7.0$)$ was Merulinidae. The coral cover in Mereni and Ferenga was lower (20\% and 10\% respectively) in 2016 surveys compared to 2010 surveys. A total of 56 genera from 13 families were recorded (Table 3). One genus (Micromussa) was only found in Grande Comore, while eight genera were unique to Mohéli. 
The most abundant fish groups were the herbivore-detritivores, with a mean abundance of 2,485 individuals per ha ( $\mathrm{SE} \pm 241.4$ ), contributing $76 \%$ of the total fish abundance (Fig. 3a). Their biomass was also the highest (Fig. 3b). The grazerdetritivores dominated the herbivore-detritivores in abundance (81\%), but in terms of biomass the Scarinae and Browsers contributed a high proportion (56\%), particularly at Sambia West and Mea in 2016 and at Ferenga in 2010. Omnivores were the most common non herbivore-detritivore trophic group, particularly in Damu and Sambia West in Moheli in 2016 and in Chindini, Grand Comore in 2010, where their biomass was greater than herb-detritivore biomass (Fig 3b). It should be noted that the additional families Haemulidae, Ephippidae and Kyphosidae included in Mohéli 2016, were minor components of the fish community comprising only $1.3 \%$ of the abundance and $3.2 \%$ of the total biomass. Corallivores densities were highest at Nioumachoua (296 ind. per ha), Mereni in 2016 (448 ind. per ha) and Bwanaidi (440 ind. per ha). Bwanaidi in Mohéli also had the highest biomass of piscivores $(79.5 \mathrm{~kg}$ per ha). Target fishery species (piscivores and omnivores) varied from maximum values of $514.5 \mathrm{~kg}$ per ha in Sambia West and $327.9 \mathrm{~kg}$ per ha at Chindini to a minimum of $5.1 \mathrm{~kg}$ per ha recorded at Mereni in 2010. In 5 of the 10 sites surveyed in Mohéli in 2016 and 6 of the 8 sites surveyed in 2010, there was $<100.0 \mathrm{~kg}$ per ha of fisheries target taxa. Comparisons between the two repeated sites in Mohéli between 2010 and 2016 suggested herbivore-detritivores were more abundant at Mereni in 2016 but not at Ferenga (Fig. 3). The fish community at Ferenga was one of the most depauperate with the lowest total abundance across all sites in both years, and in 2016 the lowest total biomass, with no omnivores observed. 
Coral fish diversity index (CFDI) values ranged from 46 species in Bwanaidi to 80 in Male (Table 4). The mean CFDI in Grand Comore was 69.3 species (SE \pm 3.50 ), which was higher than the mean CFDI of 52.5 (SE \pm 1.85 ) recorded in Mohéli 2010 and the mean of $54.8(\mathrm{SE} \pm 2.51)$ in Mohéli 2016. A greater number of species (134) were observed in Grande Comore compared to Mohéli in 2010 (103 species) and 2016 (125 species). The repeat sites Mea and Bahausi had the same CFDI value recorded in both 2010 and 2016, while the other two repeat sites, Mereni and Ferenga differed. The most speciose families at both islands were the Labridae and Pomacentridae.

Coral cover was compared with the abundance and biomass of different fish trophic groups and CFDI: corallivore abundance was positively correlated with coral cover (lm: $F=10.84, p=0.005$ ), but no other fish trophic groups were. CFDI was also not correlated with coral cover ( $\operatorname{lm}: F=0.02, p=0.888)$.

\section{Past coral bleaching impacts in PNM}

The mean maximum monthly climatology (MMM) for PNM was $29.3^{\circ} \mathrm{C}$, therefore the bleaching threshold for corals $\left(\mathrm{MMM}+1^{\circ} \mathrm{C}\right)$ was $30.3^{\circ} \mathrm{C}$. The SST trend for Mohéli shows four years where thermal stress was significant (DHW>2), during March of 1987, 1998, 2010 and 2016 (Fig. 4). The DHWs experienced in 1998 were the greatest in the time series (7.6), indicating this is when the most severe coral bleaching and mortality were likely to have taken place in PNM. Quod and Bigot (2000) surveyed Itsamia after the 1998 bleaching event and estimated 18\% mortality of corals. CORDIO's 2010 survey to PNM took place 3 weeks before SSTmax was reached, so these surveys did not capture the full extent of bleaching or mortality during 2010. Fieldwork in 2016 took place in October, six months after a period of 
thermal stress of 3.5DHWs, great enough to have caused bleaching in late March. The 2016 surveys recorded zero bleached coral colonies, but recently killed colonies were visible on some reefs. The highest mortality was recorded on the sheltered central and western sites Mereni (18.0\%), Mea (7.7\%) and Nioumachoua (6.2\%). Other sites had $<5 \%$ coral mortality and in Itsamia, there were no recently killed colonies. The site average mortality for PNM in 2016 was 5.2\% (SE \pm 1.53$)$.

\section{Vulnerability to future coral bleaching in PNM}

Physical conditions at reefs varied within PNM. The western and eastern sites were all less than $2.5 \mathrm{~km}$ to deep water (100m isobar) whereas sites in the central part of PNM and around the islands were farther away $(3-7 \mathrm{~km})$. Wave exposure was highest in the east of Mohéli and least in the central and western coastline. The wave exposure around islets was complex, ranging from highly exposed headlands to sheltered bays and channels. Shading was minimal (0-1hours) in most sites, but steep cliffs around the islets offered 3-4 hours of shading per day to these reefs. Depth was the same (10m) for all sites except Nioumachoua (5m) and Ferenga (18m).

The proportion of bleaching sensitive genera $(\mathrm{S})$ varied from $5.3 \%$ in Itsamia to $59.6 \%$ in Mea, with a PNM mean value of $27.3 \%$ (SE \pm 5.68 ) (Fig. 5). Coral communities were most thermally sensitive at islet sites, ranging from $29.9 \%$ of coral tissue area in Bahausi to 59.6\% Mea. All sites along the main coastline of Mohéli had $>75 \%$ bleaching resistant corals.

Factors contributing to recovery ability $(\mathrm{R})$ showed that Sambia West and Damu were most likely to bounce back quickly from acute disturbance, whereas Sambia East and 
Mea were least likely (Table 5). Macroalgae was low $\left(<1 \%\right.$ cover or $<400 \mathrm{~cm}^{3}$ per $\left.\mathrm{m}^{2}\right)$ in all central and western sites in PNM, with higher cover only present in Sambia East and Sambia West (Fig. 6). Sediment on reef benthos was lower in islet sites, covering an average $8.8 \%(\mathrm{SE} \pm 2.62)$ of the benthos, compared to sites along the coastline $(16.8 \% \pm 2.01 \mathrm{SE})$. Coral recruit abundance was lower in Central sites (1.1 recruits per $\mathrm{m}^{2}$ ) compared to sites along the Eastern and Western coastline $\left(2.6\right.$ recruits per $\mathrm{m}^{2}$ ). Coral recruit abundance was positively correlated with herbivore-detritivore abundance (lm: $F=13.58, p=0.006)$. Herbivore-detritivore abundance was also positively correlated with macroalgae volume ( $\mathrm{Sr}: \rho=0.648, p=0.049$ ), but showed no correlation with turf algae volume ( $\operatorname{lm}: F=1.12, p=0.322)$.

Eastern sites (Sambia West, Sambia East and Itsamia) were least likely to be impacted by thermal stress, as they had low exposure and low sensitivity to bleaching (Table 5). The potential bleaching impact $\left(\mathrm{E}^{*} \mathrm{~S}\right)$ was highest at Bahausi, Ferenga and Mea, but there were no sites that had both high exposure and high sensitivity. Nioumachoua, Damu, Bahausi and Mereni had high exposure but low sensitivity to bleaching. Conversely sites with low exposure to bleaching impacts, such as Ferenga and Mea, had more thermally sensitive coral communities (Fig. 5). Sambia West, Sambia East, Itsamia and Damu had the lowest vulnerability to bleaching, whereas Mea was highly vulnerable with high bleaching sensitivity and low recovery ability (Fig. 7). The only site with average to good scores for exposure, sensitivity and recovery was Sambia West, indicating that this site had the best all-round resilience to future coral bleaching impacts. Although Itsamia and Sambia East were likely to be only weakly impacted by thermal stress, their recovery ability was among the lowest. These two sites had the lowest coral cover observed in the park (Figs. 2 and 6). 


\section{Human pressure in PNM}

Most of the population was concentrated in the central part of PNM's coastline, with $\sim 13,000$ people living in the villages of Nrondroni and Nioumachoua giving the highest indices for fishing pressure and river pollution in central reef sites, such as Bahausi, Mea and Nioumachoua, and lowest indices in the eastern and western parts of PNM, such as Damu and Itsamia (Fig. 7, Table 6). By contrast the watersheds with the highest erosive capacity (high open land cover, low primary forest) were located in the eastern and western parts of Mohéli, whereas the central watersheds had low erosive capacity. This meant that while sites such as Damu and Itsamia were less likely to be impacted by fishing and pollution, they had high scores for vulnerability to terrestrial erosion (both 5.0). Sites around the islets had low exposure to terrestrial erosion (all <0.7), because of the high primary-forest and agro-forestry cover in central watersheds onshore from the islets, and the distance of these sites from the coastline. Combining the scores for each site for these three human stressors shows that Nioumachoua had the highest human impact score as a result of its proximity to a large population centre and two polluted rivers. All other sites had lower overall human impact scores, with Bwanaidi, Ferenga and Mereni having low scores for all three human pressures.

Coral recruit abundance was negatively correlated with river pollution score (Sr: $\rho=-$ $0.794, p=0.010$ ). Sediment cover was positively correlated with terrestrial erosion score (lm: $F=10.56, p=0.012$ ), but not with hard coral cover ( $\operatorname{lm}: F=0.065, p=0.805$ ). Notably, there was no correlation between the fishing pressure index and the biomass 
of target fishery species (Sr: $\rho=-0.551, p=0.104$ ). However, average length of target species decreased with increasing fishing pressure (Sr: $\rho=-0.818, p=0.006)$.

\section{Discussion}

\section{Reef condition in Comoros}

Coral reefs globally are being impacted by multiple stressors such as overfishing, pollution and coral bleaching which have degraded their ecological state (Bellwood et al. 2004, Burke et al. 2011). Indeed, the impacts of even low human pressure can alter reef ecology (Sandin et al. 2008), leading many reef ecologists to believe there are no 'pristine' baselines with which to compare current reef states (Knowlton and Jackson 2008). SST data suggest that coral bleaching has occurred at least five times in the Comoros during the past 40 years, and was directly observed in 1983 (Faure 1984), 1998 (Quod and Bigot 2000) and 2016. Coral mortality was 10\% in 1998 (Quod and Bigot 2000) and 5\% in 2016, which is considerably lower than in other WIO sites, where up to $90 \%$ of corals were lost in some sites in 1998 (Atewerbehan et al. 2011), and up to 50\% were lost in 2016 (Obura et al. 2017a). A recent global synthesis of thermal stress on coral reefs suggests that the NMC has received less stress than other WIO locations such as northern Tanzania and Kenya (Heron et al. 2016).

Mean coral cover values in the Indian Ocean have ranged from a mean of $40 \%$ prior to the massive bleaching event of 1997/98, dropping to around 10-20\% and then recovering to around 30\% by 2016 (Atewerbehan et al. 2011, Obura et al. 2017a). The current coral cover in the NMC ranges from $30 \%$ to $80 \%$ (Table 7), with higher coral cover in the south compared to the north (Chabanet et al. 2016). Equatorial sites in the Indian Ocean suffered the greatest thermal stress in 1998 (Obura et al. 2017a), with 
some sites, such as Kisite and Chagos, showing good recovery to $\sim 30 \%$, with others, such as Watamu, showing little improvement (Table 7).

Coral genus richness in Comoros was relatively high compared with Kenya, the Îles Éparses and the Central Indian Ocean atolls, but were similar to records from northern Mozambique and Madagascar. This likely reflects the biogeographic pattern of the NMC as a centre of biodiversity for the WIO (Obura 2012), and confirms coral diversity is not depleted in Mohéli. Two WIO endemic corals were also found: Horastrea indica and Gyrosmilia interrupta. The NMC as a centre of diversity has also been reported for reef fish (Obura et al. 2011) and the CFDI richness in Comoros confirms this with similar values to small islands in the Mozambique Channel (Îles Éparses), though slightly lower than continental Mozambique and Madagascar (Table 7).

On isolated reefs with little or no fishing, reef fish biomass has a high proportion of top trophic level piscivorous fishes (Sandin et al. 2008, Chabanet et al. 2016, Graham et al. 2017). In Comoros the fish community at all sites was dominated by herbivores, detritivores and omnivores, with very low piscivore biomass, suggesting these top predators have been depleted by fishing, which can lead to a shift in the trophic structure of the reef fish community (Graham et al. 2017). Target fishery species' biomass in Comoros (330-350 kg/ha) was, however, higher by $\sim 30 \%$ compared with other fished NMC sites. Biomass in well-protected reefs in Kenya, Îles Éparses and Chagos was 2-4 fold greater (Table 7), as reported from other regions (Sandin et al. 2008). Increased access to market and proximity to human populations is known to reduce fishery species biomass while effective no-take MPAs and a higher human development index (HDI) have been shown to increase fishery species biomass (Fox 
et al. 2014, McClanahan 2014, Cinner et al. 2016, Samoilys et al. 2017). The Comoros has one of the lowest HDI in the world (UNDP 2013), which reduces its capacity to both manage fisheries and MPAs (Fox et al. 2014). Within the Comoros, target fishery biomass was lower on average in Grande Comore compared to Mohéli and at the local scale, sites next to large population centres both in Grande Comore and on Mohéli had the lowest $(<100 \mathrm{~kg} / \mathrm{ha})$ target fishery species' biomass. In addition, target fish length decreased significantly with proximity to human population, providing further evidence for local fishing impacts.

\section{Vulnerability to future bleaching in PNM}

The vulnerability assessment revealed that sites in PNM can be loosely clustered into three main groups (Fig. 8); 'resilient islet sites' (Bwanaidi, Bahausi and Ferenga), 'resilient inshore sites' (Damu, Mereni, Nioumachou and Sambia West), and 'degraded sites' (Mea, Sambia East and Itsamia). The degraded sites have low coral cover $(<15 \%)$ and are dominated by stress tolerant slow-growing Poritidae and Merulinidae and turf algae (Fig 8A). In Itsamia, historical records of the coral community show that this reef once had higher coral cover and more Acropora (Quod and Bigot 2000). Reefs with low hard coral cover and high turf algae, proposed as a novel stable state (Bruno et al. 2009, Jouffray et al. 2015), are becoming more common in the Indo-Pacific (Obura et al. 2017a). The overall vulnerability (V) of Moheli's degraded reefs was low, because they had low sensitivity (S) and a low exposure score (E). Nevertheless, because of their low recovery (R) scores, it appears unlikely they will recover well if their exposure to bleaching increases in the future.

The 'resilient islet sites' have maintained moderate levels of hard coral cover $(\sim 30 \%)$. with reduced exposure $(\mathrm{E})$ to bleaching as a result of their proximity to deep oceanic 
water and shading from steep cliffs. This 'bleaching avoidance' is evident in their coral community, which had high levels of thermally sensitive Acropora spp. and Pocilloporidae (Fig 8B). Inshore resilient sites are more exposed to bleaching being located in shallow sheltered bays with less shading, higher water residence times and potentially greater warming. The coral community here was dominated by stress resistant massive and encrusting corals (e.g. Porites spp., Echinopora spp. and Favites spp.) (Fig 8C) suggesting that bleaching sensitive species have died and the community has adapted (West and Salm 2003). These results illustrate high variability in the resilience of reefs to bleaching within a small geographic scale and thus the potential to introduce site specific adaptive management action.

\section{Local management and recovery potential}

The recovery potential of reefs to climate change can be increased by reducing human stressors such as fishing, pollution and coastal development (West and Salm 2003, Fabricius et al. 2005, Mumby et al. 2007, Anthony et al. 2015). Unlike in many other areas of the Western Indian Ocean (e.g. Samoilys et al. 2017), herbivores are not usually targeted by artisanal fishing in Mohéli (Freed and Granek 2014, BC pers. obs.), which was evident from the high abundance of herbivore-detritivores in Moheli. This suggests that the crucial role of herbivores and detritivores in regulating algae and creating space on the reef for coral recruitment and growth (Bellwood et al. 2004, 2014; Birrell et al. 2008) is not being affected by fishing pressure.

Rivers on Mohéli are used for washing clothes, cleaning motor vehicles and getting rid of waste. We found a negative correlation between the river pollution index and coral recruit abundance suggesting that pollution may be reducing either recruitment 
or post-settlement survival (West and van Woesik 2001), However, river pollution was not correlated with either coral cover or algal biomass, indicating rivers are not significantly altering the health of reefs. For example, Nioumachoua reef, located close to Nioumachoua village and the mouths of two heavily used rivers, had the highest coral cover of any site observed in Mohéli. Reefs near coastlines of more deforested watersheds had more loose sediment, which can abrade coral and prevent coral recruitment, reducing reef resilience (Erftemeijer et al. 2012). However, terrestrial erosion was not correlated with any reduction in coral cover or recruit abundance.

Human pressures appear to be only slightly reducing reef recovery potential in Mohéli, with the least impacts around the offshore islets, when compared to more extreme pressures reported from other islands in the Comoros (Freed and Granek 2014, Audru et al. 2010). However, to avert future problems, steps should be taken to prevent further erosion and pollution entering coastal waters by protecting forest on the island's steep volcanic slopes and addressing water supply for domestic use. Current efforts being made by PNM's management to establish no-take reserves within the park will help maintain the current populations of the omnivorous and piscivorous fish that fishermen target, and prevent the herbivorous and detritivorous fish, crucial for reef recovery, from being targeted in the future.

\section{Acknowledgements}

This study was made possible by funding and logistical support provided by WWF Madagascar and in particular we would like to acknowledge the support provided by Dresy Lovasoa and Harisoa Rakotondrazafy for the work conducted in 2016. The earlier surveys in 2010 were funded through a Western Indian Ocean Marine Science Association grant to CORDIO East Africa. We appreciate 
the logistical support provided by the staff at Parc National de Mohéli and Laka Lodge for completing our fieldwork. Finally, we would like to thank Juliet Furaha, Peter Musembi, Daniel Davis and Philippe Robert for their assistance in data collection in 2016. 


\section{References}

Allen GR, \& Werner TB (2002). Coral Reef Fish Assessment in the "Coral Triangle" of Southeastern Asia. Environ. Biol. Fishes, 65(2), 209-214.

Andréfouët S, Muller-Karger FE, Robinson J, Kranenburg CJ, Torres-Pulliza D, Spraggins SA, \& Murch B. (2006). Global assessment of modern coral reef extent and diversity for regional science and management applications: a view from space. Proc 10th Int Coral Reef Symp 1732-1745.

Anthony KRN, Marshall PA, Abdulla A, Beeden R, Bergh C, Black R, Eakin MC, Game ET, Gooch M, Graham NAJ, Green A, Heron SF, Hooidonk RV, Knowland C, Mangubhai S, Marshall N, Maynard JA, McGinnity P, McLeod E, Mumby PJ, Nyström M, Obura DO, Oliver J, Possingham HP, Pressey RL, Rowland GP, Tamerlander J, Wachenfeld D \& Wear S (2015). Operationalizing resilience for adaptive coral reef management under global environmental change. Glob Chang Biol, 21(1), 48-61.

Ateweberhan M, McClanahan TR, Graham NAJ, \& Sheppard CRC (2011) Episodic heterogeneous decline and recovery of coral cover in the Indian Ocean. Coral Reefs, 30, 739-752.

Audru J-C, Bitri A, Desprats JF, Dominique P, Eucher G, Hachim S, Jossot O, Mathon C, Nédellec J-L, Sabourault P, Sedan O, Stollsteiner P, Terrier-Sedan M (2010). Major natural hazards in a tropical volcanic island: A review for Mayotte Island, Comoros archipelago, Indian Ocean. Eng Geol, 114(3-4), 364-381.

Belokurov A, Baskinas L, Biyo R, Clausen A, Dudley N, Guevara O, Lumanog J, Rakotondrazafy H, Ramahery V, Salao C, Stolton S, \& Zogib L (2016) Climate Adaptation Methodology for Protected Areas (CAMPA): Coastal and Marine. WWF, Gland, Switzerland. 160pp.

Bellwood DR, Hughes TP, Folke C, \& Nyström M (2004). Confronting the coral reef crisis. Nature, 429(6994), 827-833.

Bellwood DR, Goatley CHR, Brandl SJ, Bellwood O (2014) Fifty million years of herbivory on coral reefs: fossils, fish and functional innovations. Proc. R. Soc. B 281: 20133046.

Birrell CL, McCook LJ \& Willis BL (2008). Effects of benthic algae on the replenishment of corals and the implications for the resilience of coral reefs. Oceanography and Marine Biology, 46, 25-63.

Bruno JF, Precht WF, Vroom PS \& Aronson RB (2014). Coral reef baselines: How much macroalgae is natural? Mar Pollut Bull, 80(1-2), 24-29.

Burke, L., Reytar, K., Spalding, M. D., \& Perry, A. (2011). Reefs at risk revisited. World Resources Institute, Washington DC, USA. 130pp.

Chabanet P, Bigot L, Nicet JB, Durville P, Massé L, Mulochau T, Russo C, Tessier E, \& Obura D (2016). Coral reef monitoring in the Iles Eparses, Mozambique Channel (2011-2013). Acta Oecol, 1-11.

Cinner JE, Huchery C, MacNeil MA, Graham N, McClanahan TR, Maina J, Maire E, Kittinger JN, Hicks CC, Mora C, Allison EH, D'Agata S, Hoey A, Feary DA, Crowder L, Williams ID, Kulbicki M, Vigliola L, Wantiez L, Edgar G, StuartSmith RD, Sandin SA, Green AL, Hardt MJ, Beger M, Friedlander A, Campbell SJ, Holmes KE, Wilson SK, Brokovich E, Brooks AJ, Cruz-Motta JJ, Booth DJ, Chabanet P, Gough C, Tupper M, Ferse S, Sumalia U \& Mouillot D (2016). Bright spots among the world's coral reefs. Nature, 535(7612), 416-419.

Cinner JE, McClanahan TR, Graham N, Daw TM, Maina J, Stead SM, Wamukota A, Brown K \& Bodin Ö. (2012). Vulnerability of coastal communities to key impacts of climate change on coral reef fisheries. Glob Environ Change, 22, 12- 
20.

Coles SL \& Jokiel PL (1978). Synergistic effects of temperature, salinity and light on the hermatypic coral Montipora verrucosa. Mar Biol, 49(3), 187-195.

Cowburn B (2016) Coral reefs and climate change in the Indian Ocean: A case study of Watamu Marine National Park and other Indian Ocean Locations. PhD Thesis, University of Oxford, UK, 287pp.

Erftemeijer PLA, Riegl B, Hoeksema BW \& Todd PA (2012). Environmental impacts of dredging and other sediment disturbances on corals: A review. Mar Pollut Bull, 64(9), 1737-1765.

Fabricius KE (2005). Effects of terrestrial runoff on the ecology of corals and coral reefs: review and synthesis. Mar Pollut Bull, 50(2), 125-146.

Faure G, Guillaume M \& Payri C (1984). Sur un phénomène remarquable de blanchiment et de mortalité massive des madréporaires dans le complexe recifal de l'ile Mayotte (SW Ocean Indien). C. R. Acad. Sc. Paris 299 (15), 637-642

Fox HE, Holtzman JL, Haisfield KM, McNally CG, Cid GA, Mascia MB, Parks JE \& Pomeroy RS (2014). How Are Our MPAs Doing? Challenges in Assessing Global Patterns in Marine Protected Area Performance. Coast Manage, 42(3), 207-226.

Freed S \& Granek EF (2014). Effects of Human Activities on the World's Most Vulnerable Coral Reefs: Comoros Case Study. Coast Manage, 42(3), 280-296.

Gough C (2012). Assessment of the vulnerability to climate change of the traditional fishing communities of Nosy Hara, northwest Madagascar: Part of the Capacity for adaptation to Climate Change, Madagascar. WWF Project MG 950.

Graham N, McClanahan TR, MacNeil MA, Wilson SK, Cinner JE, Huchery C \& Holmes TH (2017). Human Disruption of Coral Reef Trophic Structure. Curr Biol, 27(2), 231-236.

Granek EF \& Brown MA (2005). Co-Management Approach to Marine Conservation in Mohéli, Comoros Islands. Conserv Biol, 19(6), 1724-1732.

Green AL \& Bellwood DR (2009). Monitoring functional groups of herbivorous reef fishes as indicators of coral reef resilience (pp. 1-70). IUCN working group on climate change and coral reefs. IUCN, Gland, Switzerland.

Hawlitschek O, Brückmann B, Berger J, Green K \& Glaw F (2001) Integrating field surveys and remote sensing data to study distribution, habitat use and conservation status of the herpetofauna of the Comoro Islands. ZooKeys 144: 2179

Heron SF, Maynard JA, van Hooidonk R, \& Eakin CM (2016). Warming Trends and Bleaching Stress of the World's Coral Reefs 1985-2012. Scientific Reports, 6, 38402.

Harris JL, Estradivari E, Fox HE, McCarthy OS, \& Ahmadia GN (2017). Planning for the future: Incorporating global and local data to prioritize coral reef conservation. Aquatic Conservation: Marine and Freshwater Ecosystems, 27(S1), 65-77.

Hughes TP, Rodrigues MJ, Bellwood DR, Ceccarelli D, Hoegh-Guldberg O, McCook L, et al. Phase Shifts, Herbivory, and the Resilience of Coral Reefs to Climate Change. Current Biology. 2007; 17: 360-365.

Jouffray JB, Nyström M, Norström AV, Williams ID, Wedding LM, Kittinger JN \& Williams GJ (2015). Identifying multiple coral reef regimes and their drivers across the Hawaiian archipelago. Philos Trans R Soc Lond B Biol Sci, 370(1659), 20130268.

Knowlton N \& Jackson JBC (2008). Shifting baselines, local impacts, and global 
change on coral reefs. PLoS Biology, 6(2), e54.

Kohler KE \& Gill SM (2006). Coral Point Count with Excel extensions (CPCe): A Visual Basic program for the determination of coral and substrate coverage using random point count methodology. Comput Geosci, 32, 1259-1269.

Liu G, Strong AE \& Skirving W (2003). Remote sensing of sea surface temperatures during 2002 Barrier Reef coral bleaching. Eos, Transactions American Geophysical Union, 84(15), 137-141.

Loya Y, Sakai K, Yamazato K, Nakano Y, Sambali H \& Van Woesik R (2001). Coral bleaching: the winners and the losers. Ecol Lett, 4(2), 122-131.

Maynard JA, Marshall PA, Johnson JE \& Harman S (2010). Building resilience into practical conservation: identifying local management responses to global climate change in the southern Great Barrier Reef. Coral Reefs, 29(2), 381-391.

McClanahan TR (2014). Recovery of functional groups and trophic relationships in tropical fisheries closures. Marine Ecology Progress Series, 497, 13-23.

McClanahan TR, Ateweberhan M \& Graham N (2007). Western Indian Ocean coral communities: bleaching responses and susceptibility to extinction. Mar Ecol Prog Ser, 337, 1-13.

McClanahan TR, Donner SD, Maynard JA, MacNeil MA, Graham N, Maina J, Baker AC, Alemu JB, Beger M, Campbell SJ, Darling ES, Eakin M, Heron SF, Jupiter SD, Lunquist CJ, McLeod E, Mumby PJ, Paddack MJ, Selig ER \& van Woesik R (2012). Prioritizing key resilience indicators to support coral reef management in a changing climate. PLOS ONE, 7(8), e42884.

McClanahan TR, Graham NAJ \& Darling ES (2014). Coral reefs in a crystal ball: predicting the future from the vulnerability of corals and reef fishes to multiple stressors. Curr Opin Environ Sustain, 7, 59-64.

Mumby PJ, Dahlgren CP, Harborne AR, Kappel CV, Micheli F, Brumbaugh DR, et al. (2006). Fishing, trophic cascades, and the process of grazing on coral reefs. Science (New York, N.Y.), 311(5757), 98-101.

Mumby, P. J., Hastings, A., \& Edwards, H. J. (2007). Thresholds and the resilience of Caribbean coral reefs. Nature, 450(7166), 98-101.

Obura DO (2005). Resilience and climate change: lessons from coral reefs and bleaching in the Western Indian Ocean. Estuarine, Coastal and Shelf Science, 63(3), 353-372.

Obura DO (2012). The Diversity and Biogeography of Western Indian Ocean ReefBuilding Corals. PLoS ONE, 7(9), e45013.

Obura DO \& Grimsditch G (2009). Resilience Assessment of coral reefs - Assessment protocol for coral reefs, focusing on coral bleaching and thermal stress. IUCN Working Group on Climate Change and Coral Reefs, IUCN, Gland, Switzerland, $1-70$.

Obura DO, Di Carlo G, Rabearisoa A \& Oliver T (editors). 2011. A Rapid Marine Biodiversity Assessment of the coral reefs of northeast Madagascar. RAP Bulletin of Biological Assessment 61. Conservation International. Arlington, VA.

Obura DO, Church J.E., Gabriel C. (2012) Assessing marine heritage from an ecosystem perspective: the western Indian Ocean. World Heritage Centre, United Nations Education, Science and Cultural Organization (UNESCO). 124 pp.

Obura DO, Burgener V, Nicoll ME, Ralison HO \& Scheren P (2015) The Northern Mozambique Channel. Setting the foundations for a regional approach to marine governance. A Background Document. WWF International and CORDIO East Africa.

Obura DO, Gudka M, Bijoux J, Freed S, Gian SB, Maharavo J, Mwaura J, Porter S, 
Sola E, Wickel J, Yahya S and Ahamada S (2017a) Coral reef status report for the Western Indian Ocean. Global Coral Reef Monitoring Network (GCRMN)/ International Coral Reef Initiative (ICRI). pp 140.

Obura, DO., McPhillips, J., Chaudhry, T., Gamblin, P., Burgener, V., Owen, S. \& Gonzales, A. (2017b). Reviving the Western Indian Ocean Economy: Actions for a Sustainable Future. WWF International, Gland, Switzerland. 64 pp.

Quod J \& Bigot L (2000). Coral bleaching in the Indian Ocean islands, Ecological consequences and recovery in Madagascar, Comoros, Mayotte and Reunion. Coral Reef Degradation in the Indian Ocean (CORDIO) Status Report 2000 (pp. 108-113), SAREC Marine Science Program, Stockholm, Sweden.

Rocliffe S, Peabody S, Samoilys M \& Hawkins JP (2014). Towards A Network of Locally Managed Marine Areas (LMMAs) in the Western Indian Ocean. PLoS ONE, 9(7), e103000-14.

Samoilys MA \& Carlos G (2000). Determining Methods of Underwater Visual Census for Estimating the Abundance of Coral Reef Fishes. Environ Biol Fishes, 57(3), 289-304.

Samoilys MA, Roche R, Koldewey H \& Turner J (unpublished) Patterns in reef fish assemblages: insights from the Chagos Archipelago. Plos One: In review.

Sandin SA, Smith JE, DeMartini EE, Dinsdale EA, Donner SD, Friedlander AM, Konotchick T, Malay M, Maragos JE, Obura D, Pantos O, Paulay M, Richie M, Rohwer F, Schroeder RE, Walsh S, Jackson J, Knowlton N \& Sala E (2008). Baselines and Degradation of Coral Reefs in the Northern Line Islands. PLoS ONE, 3(2), e1548.

Schott FA, Xie S-P \& McCreary JP (2009). Indian Ocean circulation and climate variability. Rev Geophys, 47(1), RG1002-46.

UNDP (2013) Human development report 2013, the rise of the south; human progress in a diverse world: Comoros. United Nations Development Programme, NY, USA. 4pp.

West JM \& Salm RV (2003). Resistance and resilience to coral bleaching: implications for coral reef conservation and management. Conserv Biol, 14(4), 956-967.

West K \& van Woesik R (2001). Spatial and temporal variance of river discharge on Okinawa (Japan): Inferring the temporal impact on adjacent coral reefs. Mar Pollut Bull, 42(10), 864-872.

Wilkinson C (2008). Status of Coral Reefs of the World: 2008. Global Coral Reef Monitoring Network and Reef and Rainforest Research Centre, Townsville, Australia, 1-296.

Yuan Y, Jiang Y, Taguas EV, Mbonimpa EG \& Hu W (2015). Sediment loss and its cause in Puerto Rico watersheds. Soil, 1(2), 595-602. 


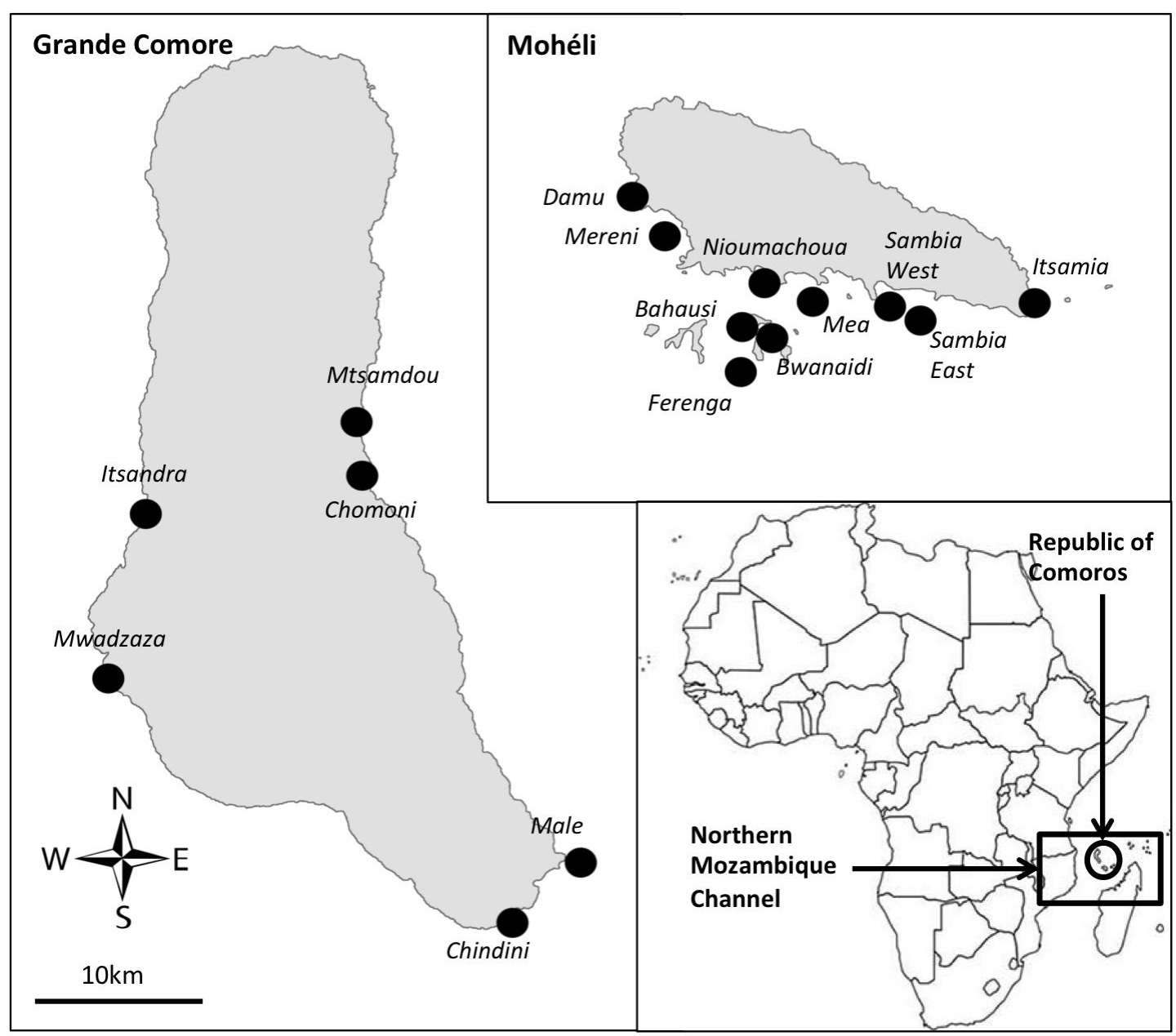

Figure 1. Maps of Grande Comore and Mohéli showing survey sites with an inset showing the position of Northern Mozambique Channel (NMC) the Comoros archipelago within Africa. 

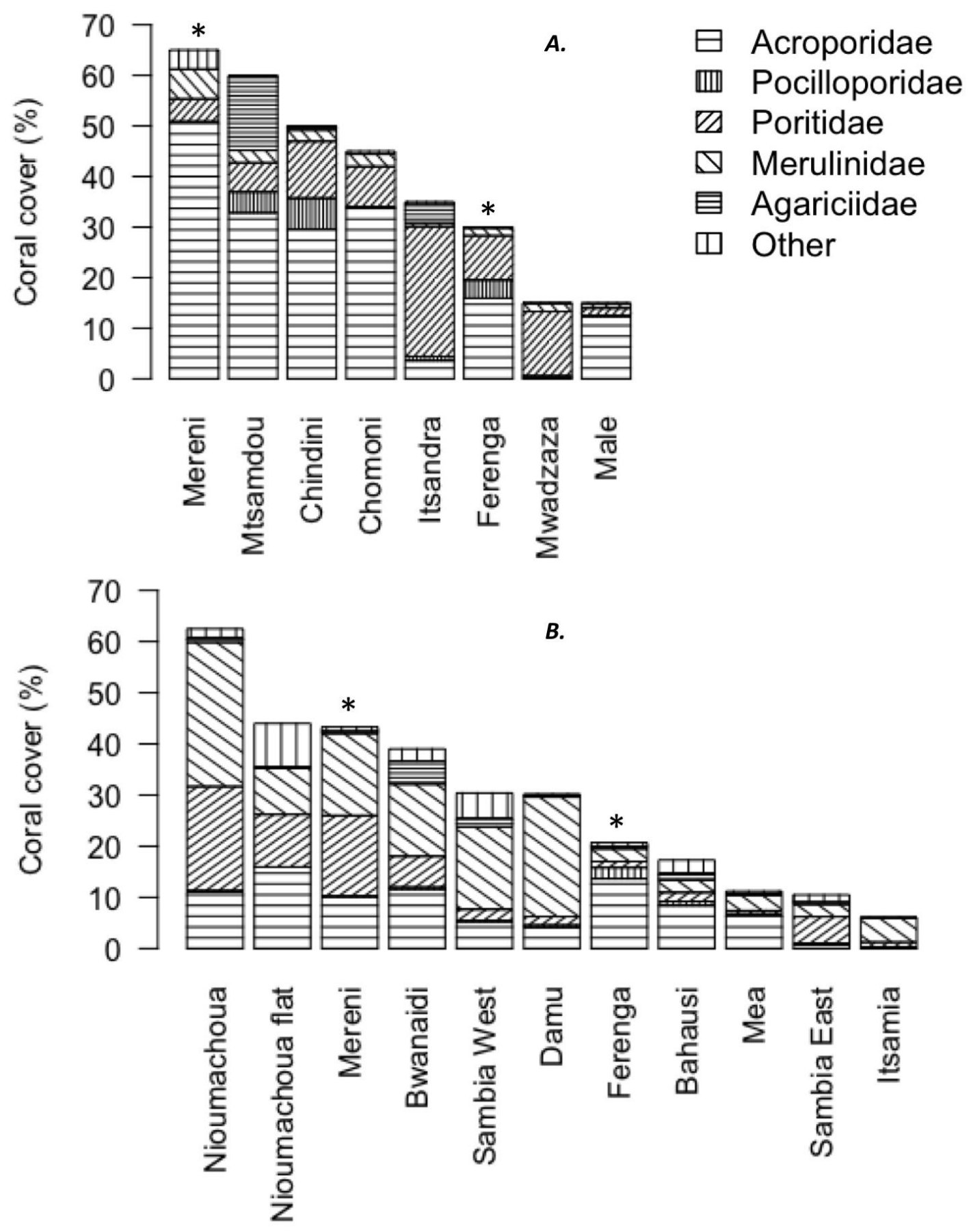

Figure 2. Coral cover, showing the composition of major coral families, by sites investigated in a) 2010 and b) 2016 in Mohéli. * = repeated sites. 

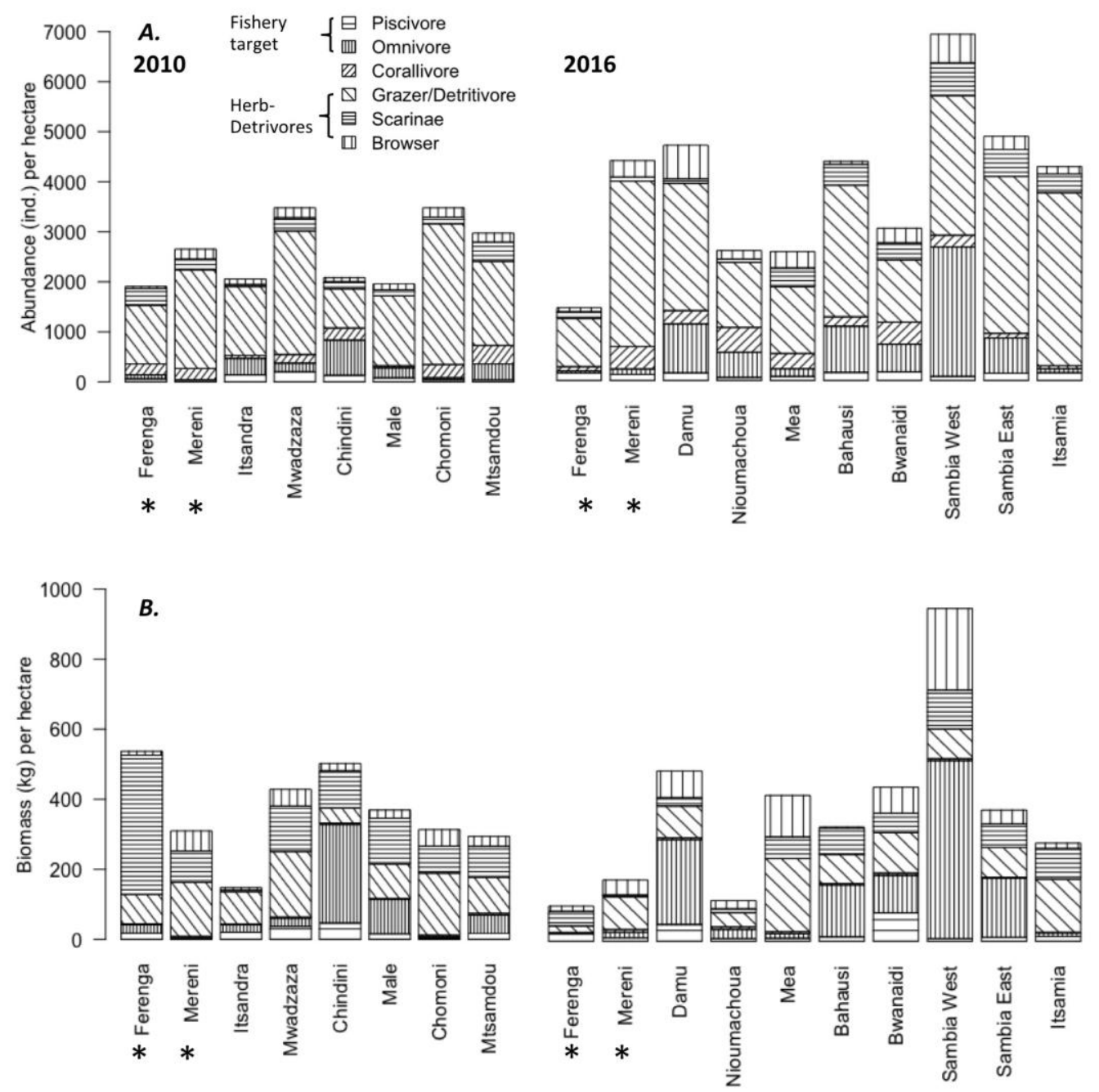

Figure 3. Fish abundance (a) and biomass (b) at sites surveyed in 2010 and 2016. * $=$ repeated sites. Further details on trophic groups are provided in Table S2. The herbivore-detritivores aggregate 7 trophic groups. Note additional trophic groups in 2016 were Haemulidae in the omnivores, and Kyphosidae and Siganidae in the Browsers. 


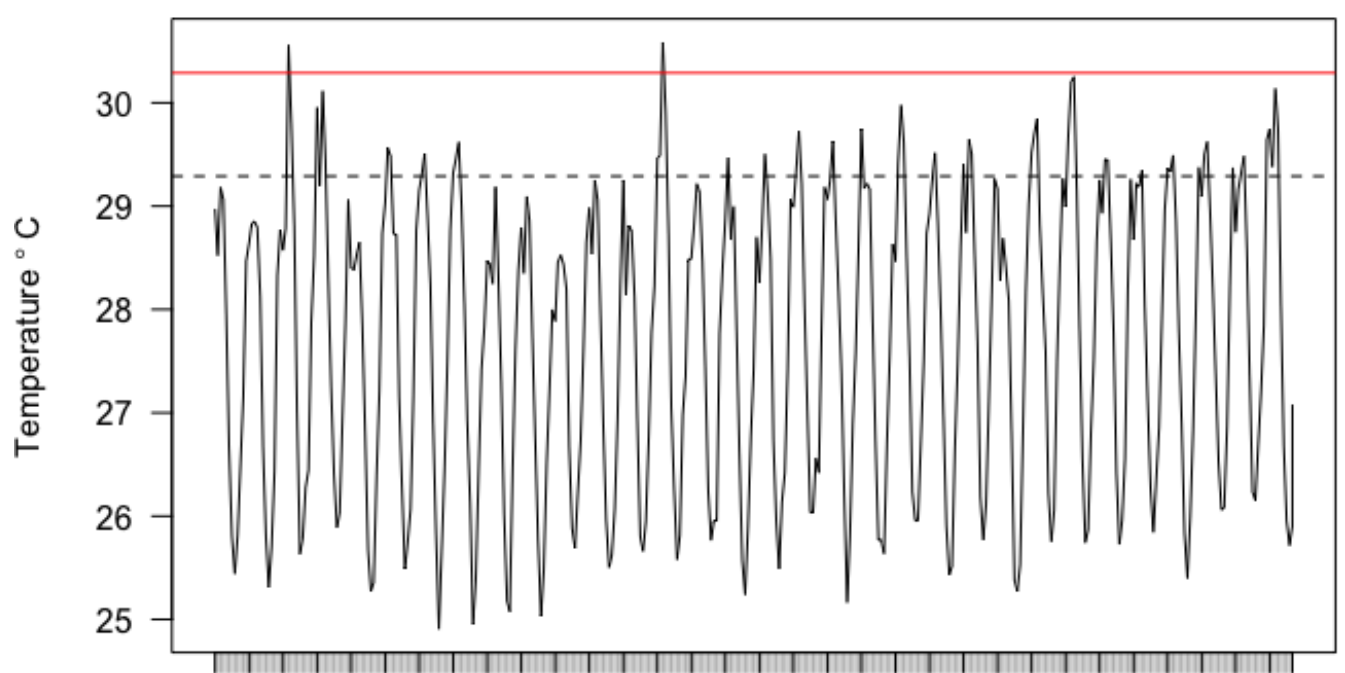

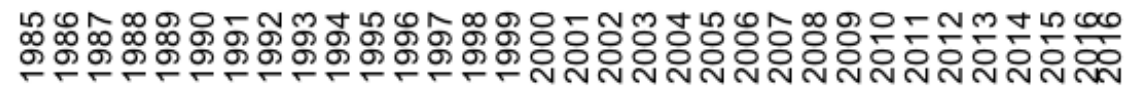

Figure 4. Monthly average SST for PNM from 1985-2016. Black dashed line indicates $\mathrm{MMM}$, red line indicates the bleaching threshold $\left(\mathrm{MMM}+1^{\circ} \mathrm{C}\right)$ 


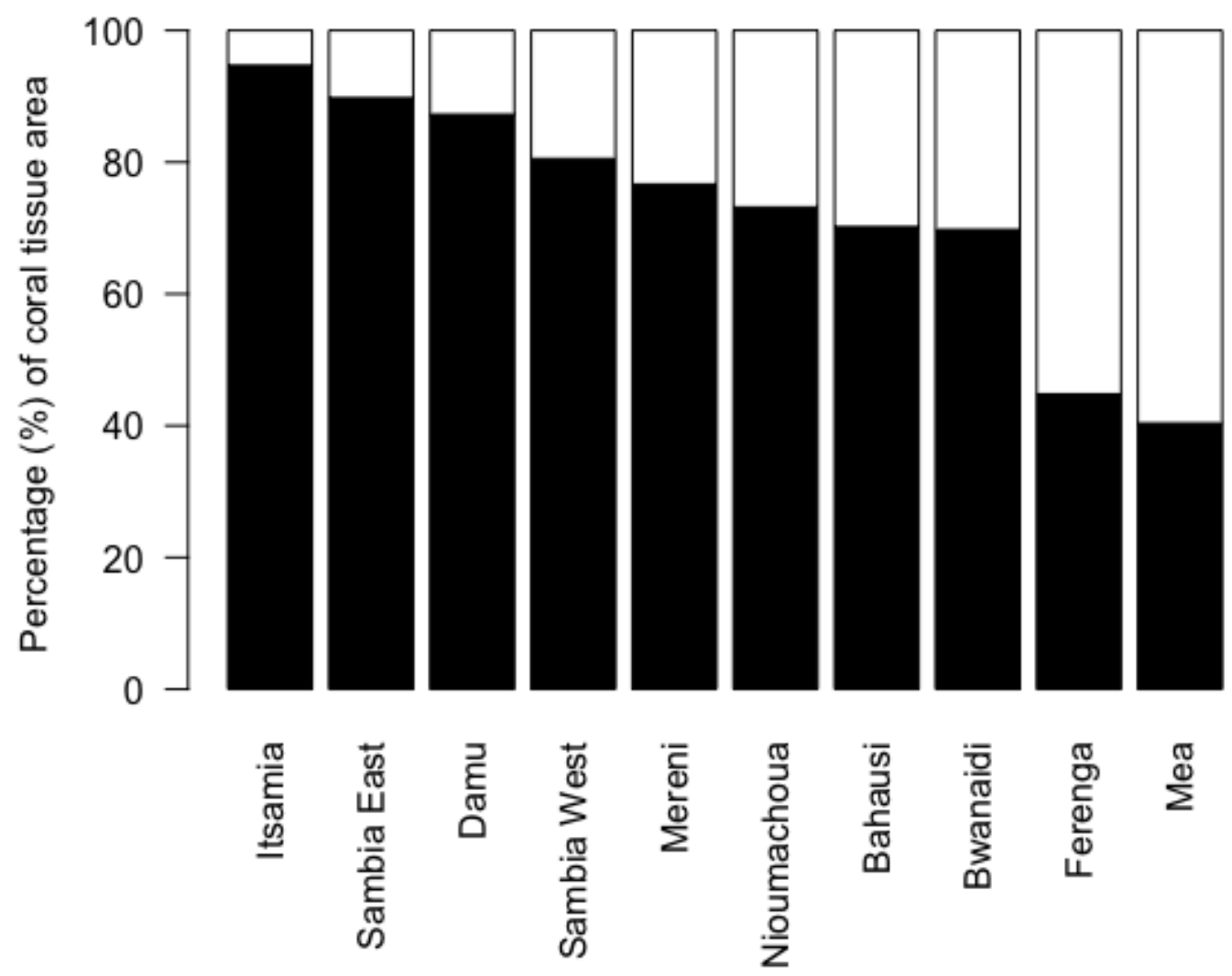

Figure 5. The percentage of coral area composed of thermally sensitive genera Acropora, Alveopora, Montipora, Pocillopora, Seriatopora, Stylophora and branching Porites (white) and all other more thermally tolerant genera (black).

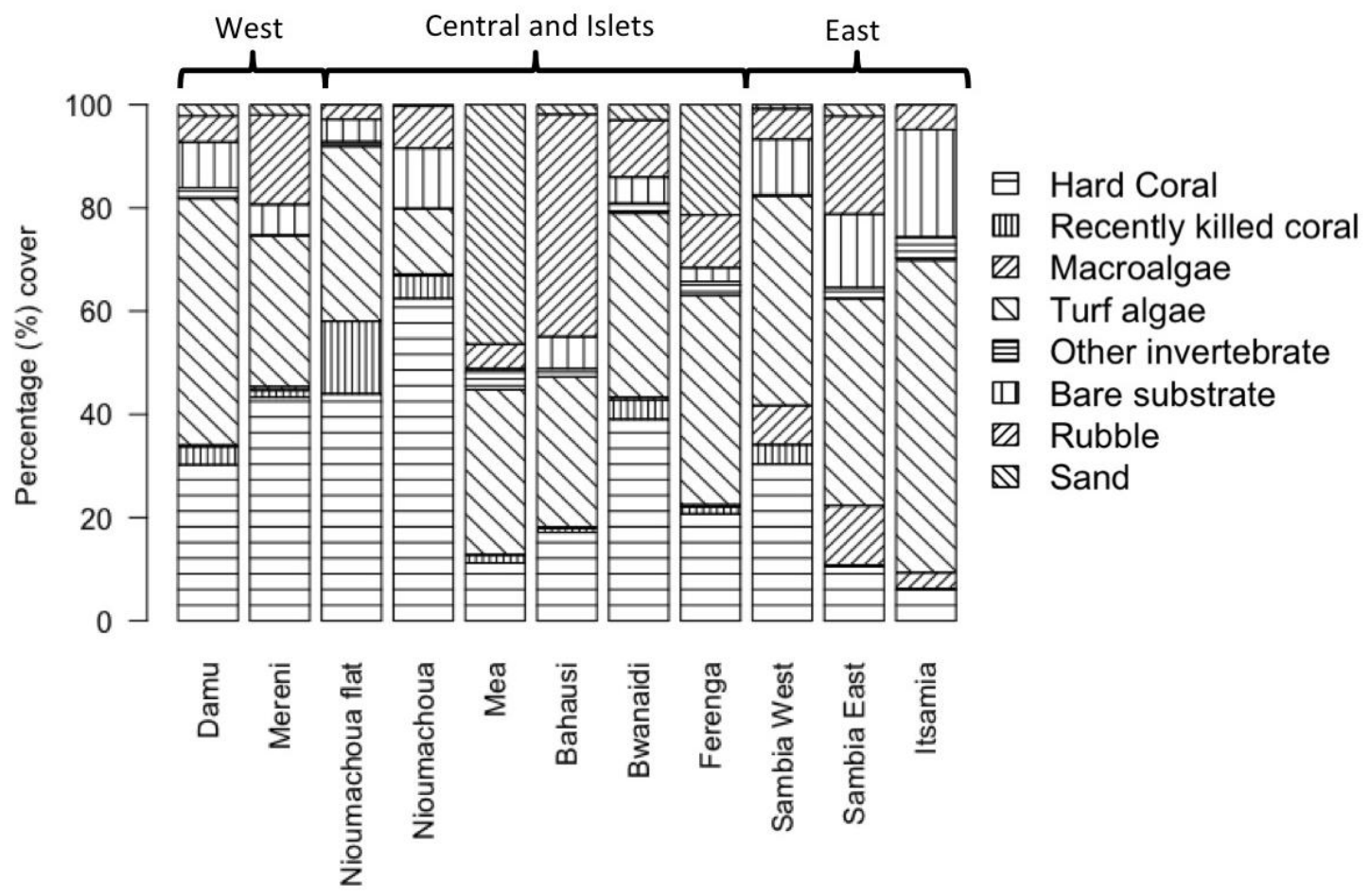

Figure 6. Benthic cover (\%) of major categories by site arranged West to East. 

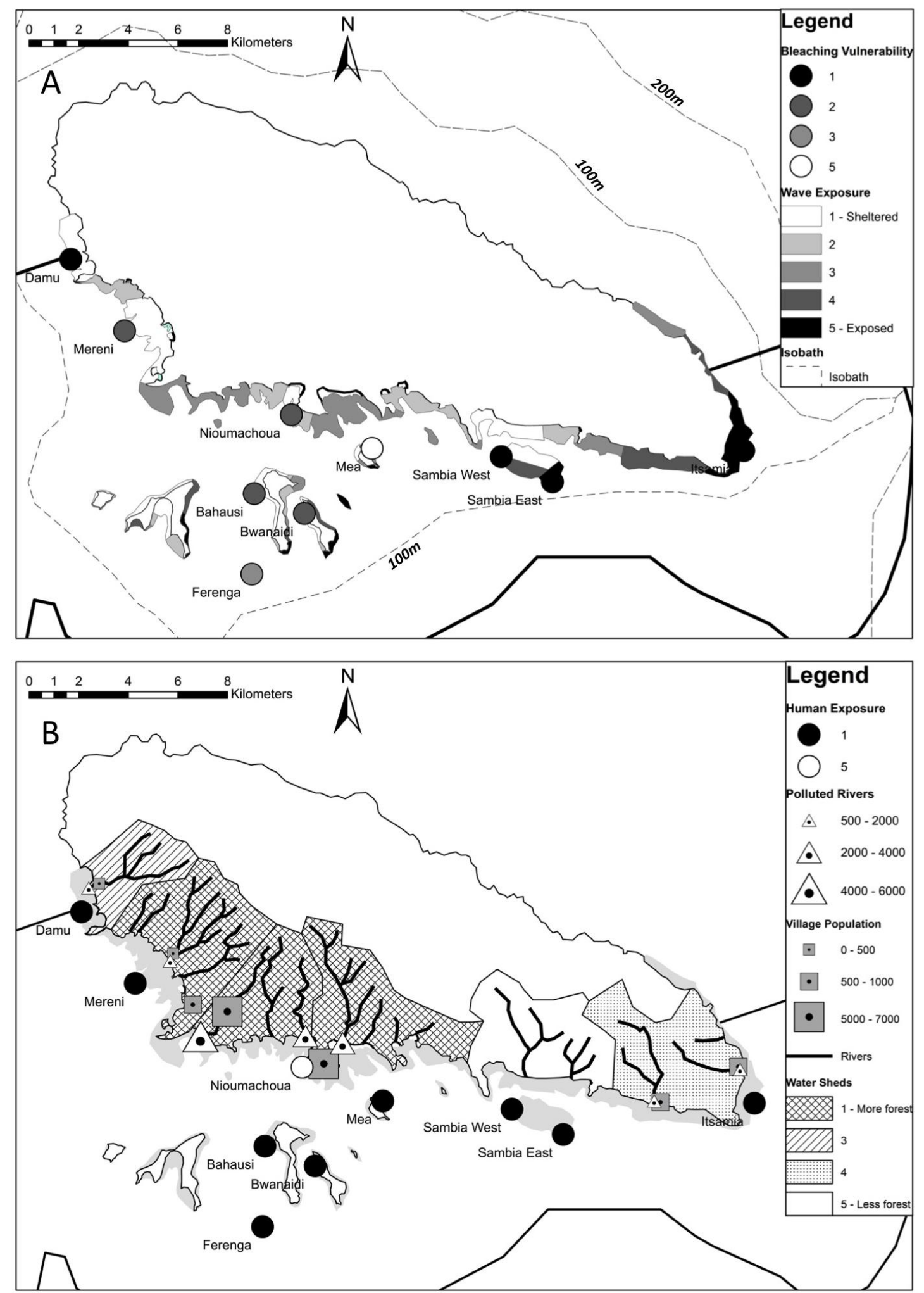

Figure 7. Maps of Mohéli showing A. the bleaching vulnerability of sites along with wave exposure and coastal isobaths and $\mathrm{B}$. human threats and site exposure to threats in PNM. Villages, polluted rivers and watersheds are shown with the size of population living in villages and using rivers is indicated. Watershed score reflects the forest cover and hence the erosive capacity of the soil. 


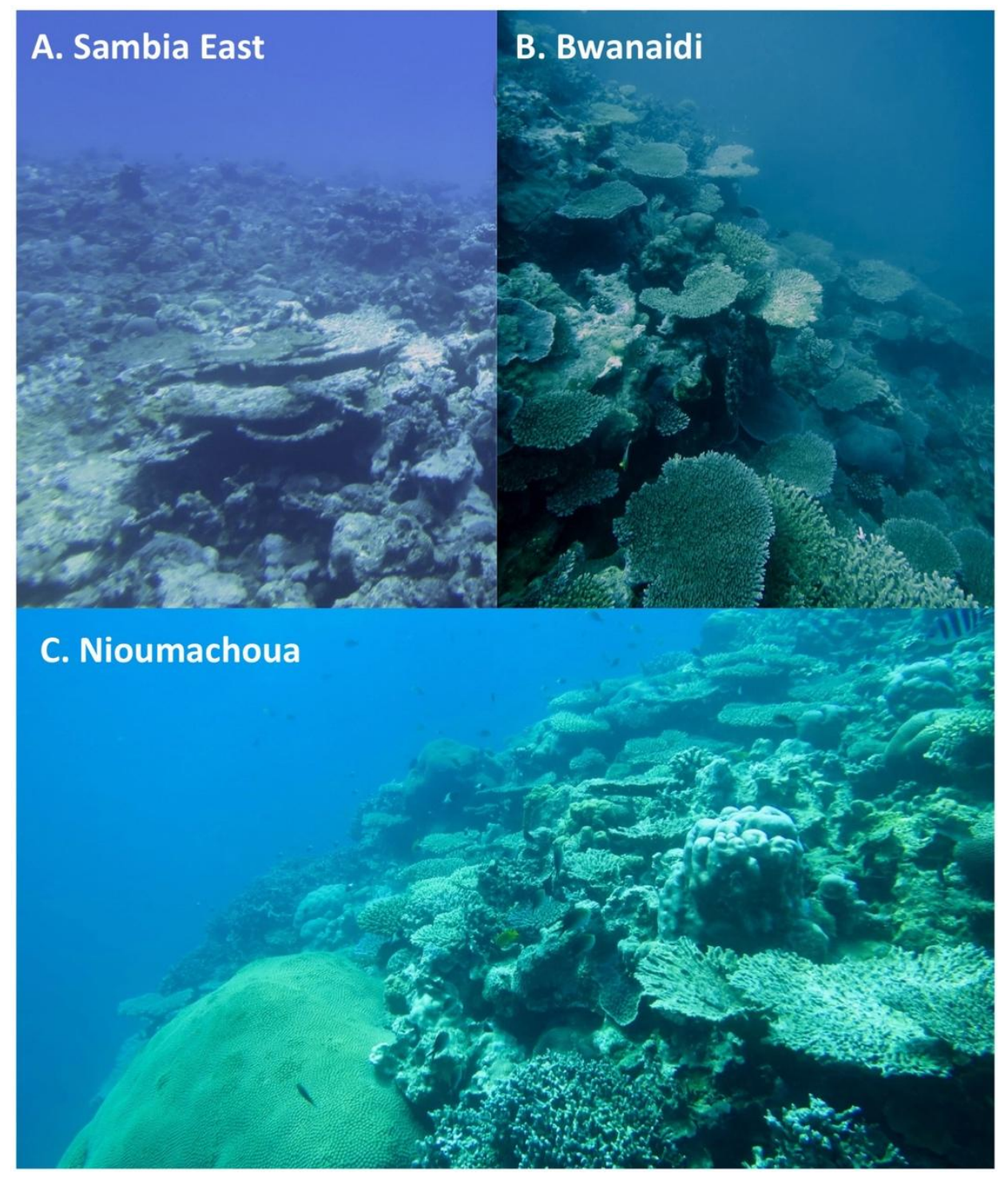

Figure 8. Snapshots of reef condition in PNM, showing A. low cover of corals and high algal cover in Sambia East; B. high coral cover with thermally sensitive corals, such as table Acropora in Bwanaidi; and C. high coral cover of thermally resistant corals, such as massive Porites and Diploastrea in Nioumachoua. 
Table 1. Indicators used for assessing reef condition and bleaching exposure, sensitivity and recovery, showing their units and data sources.

\begin{tabular}{|c|c|c|c|}
\hline & Indicator & Unit & Data Source \\
\hline \multirow{4}{*}{$\begin{array}{l}\text { Reef } \\
\text { Condition }\end{array}$} & Coral cover & Percentage (\%) & Quadrats, $1 \mathrm{~m}^{2}$ \\
\hline & Coral genus richness & No. of genera & Random swim \\
\hline & $\begin{array}{l}\text { Target fish biomass } \\
\text { (Piscivore \& } \\
\text { Omnivore) }\end{array}$ & kg per hectare & $\begin{array}{l}\text { Fish belt } \\
\text { transects, } 250 \mathrm{~m}^{2}\end{array}$ \\
\hline & $\begin{array}{l}\text { Coral Fish Diversity } \\
\text { Index (CFDI) }\end{array}$ & No. of species & $\begin{array}{l}75 \text { minute } \\
\text { species count }\end{array}$ \\
\hline \multirow{4}{*}{$\begin{array}{l}\text { Bleaching } \\
\text { Exposure (E) }\end{array}$} & Wave exposure & Degrees $\left({ }^{\circ}\right)$ & GIS \\
\hline & $\begin{array}{l}\text { Distance to deep } \\
\text { water }\end{array}$ & Kilometres $(\mathrm{km})$ & GIS \\
\hline & Shading & Hours (hrs) & Field observation \\
\hline & Depth & Metres (m) & Field observation \\
\hline $\begin{array}{l}\text { Bleaching } \\
\text { Sensitivity (S) }\end{array}$ & $\begin{array}{l}\text { Thermally sensitive } \\
\text { corals }\end{array}$ & Percentage (\%) & $\begin{array}{l}\text { Coral belt } \\
\text { transect } 10 \mathrm{~m}^{2}\end{array}$ \\
\hline \multirow{6}{*}{$\begin{array}{l}\text { Bleaching } \\
\text { Recovery (R) }\end{array}$} & Turf algae & $\mathrm{Cm}^{3}$ per $\mathrm{m}^{2}$ & Quadrats, $1 \mathrm{~m}^{2}$ \\
\hline & Macroalgae & $\mathrm{Cm}^{3}$ per $\mathrm{m}^{2}$ & Quadrats, $1 \mathrm{~m}^{2}$ \\
\hline & $\begin{array}{l}\text { Recruitment - Coral } \\
\text { recruits }\end{array}$ & No. per $\mathrm{m}^{2}$ & Quadrats, $1 \mathrm{~m}^{2}$ \\
\hline & $\begin{array}{l}\text { Herbivore-detrivore } \\
\text { fish density }\end{array}$ & $\begin{array}{l}\text { Individual per } \\
\text { hectare }\end{array}$ & $\begin{array}{l}\text { Fish belt } \\
\text { transects, } 250 \mathrm{~m}^{2}\end{array}$ \\
\hline & Solid substrate & Percentage (\%) & Quadrats, $1 \mathrm{~m}^{2}$ \\
\hline & Loose sediment & Percentage (\%) & Quadrats, $1 \mathrm{~m}^{2}$ \\
\hline
\end{tabular}


Table 2. Conversion for indicators from raw value to indicators scores used to assess bleaching vulnerability, showing the range in indicator values observed during fieldwork in Mohéli 2016 and the category boundaries for each score arranged from best (top) to worst (bottom). *Depth was scored as ' 3 ' for all sites at $10 \mathrm{~m}$, ' 2 ' for Ferenga (18m) and '4' for Nioumachoua (5m).

\begin{tabular}{|c|c|c|c|c|c|c|c|c|c|c|c|c|}
\hline & \multicolumn{4}{|c|}{ Bleaching Exposure } & $\begin{array}{l}\text { Bleaching } \\
\text { Sensitivity } \\
\text { Sensitive } \\
\text { Corals }\end{array}$ & & \multicolumn{6}{|c|}{ Bleaching Recovery } \\
\hline Range & $\begin{array}{c}0- \\
4 h r s\end{array}$ & $\begin{array}{c}0.7- \\
6.8 \mathrm{~km}\end{array}$ & $0-90^{\circ}$ & $\begin{array}{c}5- \\
18 m^{*}\end{array}$ & $\begin{array}{c}5.3- \\
16.1 \% \\
\end{array}$ & Range & $\begin{array}{c}240- \\
1190 \mathrm{~cm}^{3}\end{array}$ & $0-6128$ & $\begin{array}{c}0.66-3.25 \\
\text { per m }\end{array}$ & $\begin{array}{l}\text { 1128-3968 } \\
\text { ind. per ha }\end{array}$ & $3.9-23.7 \%$ & \begin{tabular}{|l|}
$48.8-$ \\
$95.2 \%$ \\
\end{tabular} \\
\hline 1 & Ohrs & $\begin{array}{c}0.7- \\
1.9 \mathrm{~km}\end{array}$ & $73-90^{\circ}$ & - & $\begin{array}{c}5.3- \\
16.1 \%\end{array}$ & 5 & $\begin{array}{c}240- \\
429 \mathrm{~cm}^{3}\end{array}$ & $0-1239 \mathrm{~cm}^{3}$ & $\begin{array}{c}2.74-3.25 \\
\text { per } \mathrm{m}^{2}\end{array}$ & $\begin{array}{l}\text { 3404-3968 } \\
\text { ind. per ha }\end{array}$ & $3.9-7.8 \%$ & $\begin{array}{l}85.9- \\
95.2 \%\end{array}$ \\
\hline 2 & $1 \mathrm{hr}$ & $\begin{array}{c}2.0- \\
3.2 \mathrm{~km}\end{array}$ & $55-72^{\circ}$ & $18 \mathrm{~m}$ & $\begin{array}{l}16.2- \\
27.0 \%\end{array}$ & 4 & $\begin{array}{c}430- \\
619 \mathrm{~cm}^{3}\end{array}$ & $\begin{array}{c}1240- \\
2479 \mathrm{~cm}^{3}\end{array}$ & $\begin{array}{c}2.22-2.73 \\
\text { per m }\end{array}$ & $\begin{array}{l}2835-3403 \\
\text { ind. per ha }\end{array}$ & $7.9-11.8 \%$ & $\begin{array}{l}76.6- \\
85.8 \%\end{array}$ \\
\hline 3 & $2 \mathrm{hrs}$ & $\begin{array}{c}3.3- \\
4.4 \mathrm{~km}\end{array}$ & $37-54^{\circ}$ & $10 \mathrm{~m}$ & $\begin{array}{c}27.1- \\
37.9 \% \\
\end{array}$ & 3 & $\begin{array}{c}620- \\
809 \mathrm{~cm}^{3}\end{array}$ & $\begin{array}{c}2480- \\
3719 \mathrm{~cm}^{3}\end{array}$ & $\begin{array}{c}1.70-2.21 \\
\text { per m }{ }^{2}\end{array}$ & $\begin{array}{l}2266-2834 \\
\text { ind. per ha }\end{array}$ & $11.9-15.8 \%$ & $\begin{array}{l}67.3- \\
75.5 \% \\
\end{array}$ \\
\hline 4 & $3 \mathrm{hrs}$ & $\begin{array}{c}4.5- \\
5.6 \mathrm{~km}\end{array}$ & $19-36^{\circ}$ & $5 m$ & $\begin{array}{l}38.0- \\
48.8 \%\end{array}$ & 2 & $\begin{array}{c}810- \\
999 \mathrm{~cm}^{3}\end{array}$ & $\begin{array}{c}3720- \\
4959 \mathrm{~cm}^{3}\end{array}$ & $\begin{array}{c}1.18-1.69 \\
\text { per } \mathrm{m}^{2}\end{array}$ & $\begin{array}{l}\text { 1697-2265 } \\
\text { ind. per ha }\end{array}$ & $15.9-19.7 \%$ & $\begin{array}{l}58.1- \\
67.2 \%\end{array}$ \\
\hline 5 & $4 \mathrm{hrs}$ & $\begin{array}{c}5.7- \\
6.8 \mathrm{~km}\end{array}$ & $0-18^{\circ}$ & - & $\begin{array}{c}48.9- \\
59.7 \%\end{array}$ & 1 & $\begin{array}{c}1000- \\
1190 \mathrm{~cm}^{3}\end{array}$ & $\begin{array}{c}4960- \\
6128 \mathrm{~cm}^{3}\end{array}$ & $\begin{array}{c}0.66- \\
1.17 \text { per } \\
\mathrm{m}^{2}\end{array}$ & $\begin{array}{l}\text { 1128-1696 } \\
\text { ind. per ha }\end{array}$ & $19.8-23.7 \%$ & $\begin{array}{c}48.8- \\
58.0 \%\end{array}$ \\
\hline
\end{tabular}


Table 3. Coral families and genera observed in Grande Comore and Mohéli. The number of genera per family is indicated in parentheses. Relative abundance score: $1=$ Rare, 2 = Uncommon, 3 = Common, 4=Abundant and 5=Dominant

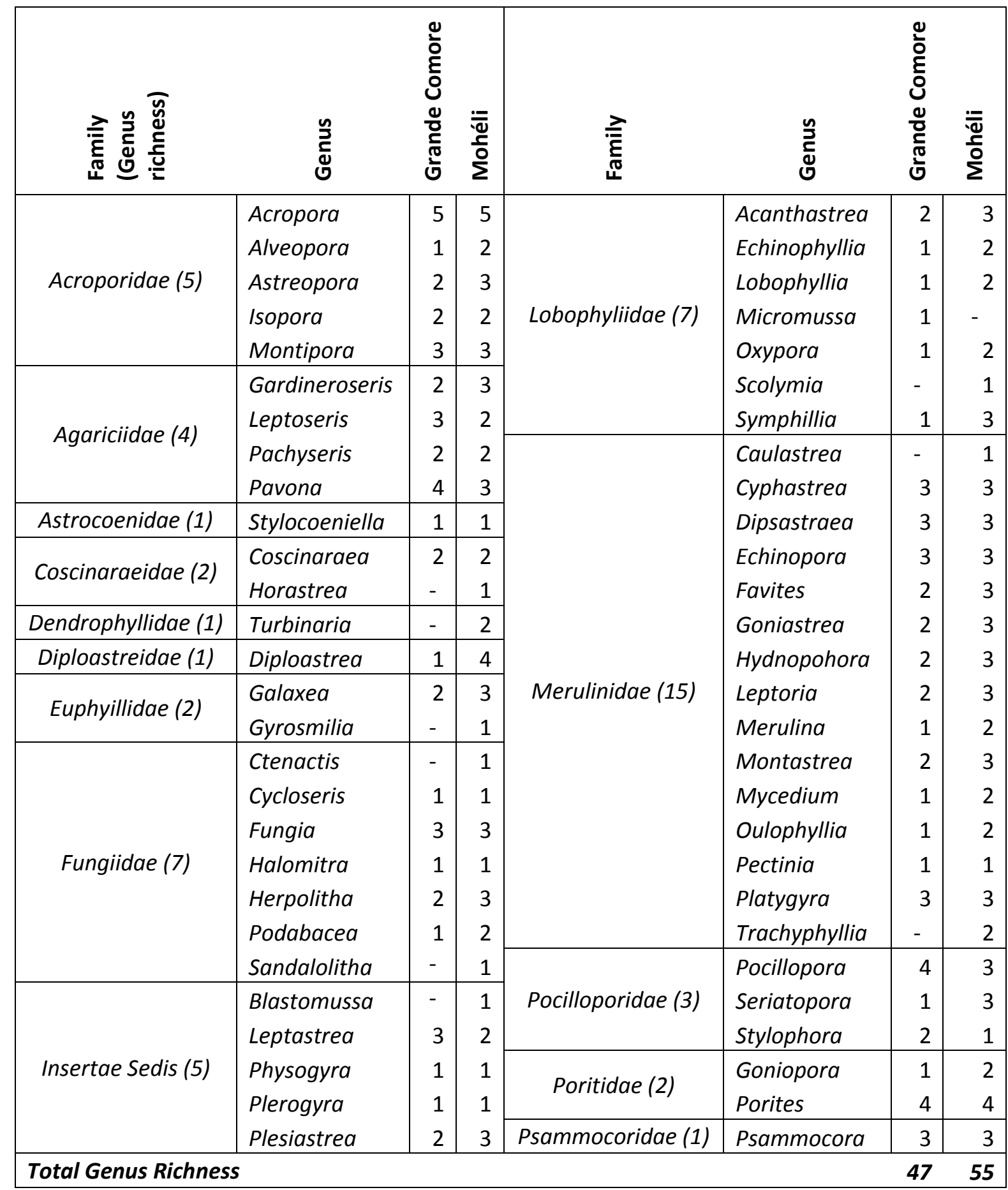


Table 4. Species richness of the six fish families used in the Coral Fish Diversity Index (CFDI), showing CFDI by site, island and year. Repeated sites in 2010 and 2016 are indicated (*).

\begin{tabular}{|c|c|c|c|c|c|c|c|c|c|c|c|c|c|c|c|c|c|}
\hline & & 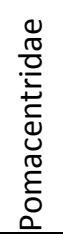 & 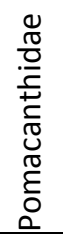 & $\begin{array}{l}0 \\
\frac{0}{0} \\
\frac{0}{0} \\
\frac{0}{0} \\
\stackrel{0}{J}\end{array}$ & 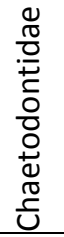 & $\begin{array}{l}\frac{0}{\pi} \\
\frac{\pi}{0} \\
\frac{0}{\pi} \\
\tilde{U} \\
\end{array}$ & 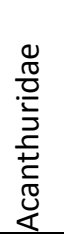 & 递 & & & 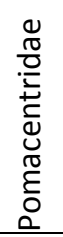 & 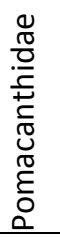 & $\begin{array}{l}0 \\
\frac{0}{0} \\
\frac{0}{0} \\
0 \\
0 \\
0 \\
\end{array}$ & $\begin{array}{l}0 \\
\frac{\pi}{0} \\
.0 \\
0 \\
0 \\
0 \\
0 \\
0 \\
0 \\
0 \\
\frac{\pi}{U} \\
\frac{c}{U}\end{array}$ & 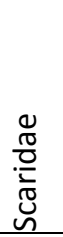 & 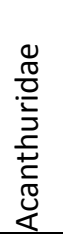 & ত্ \\
\hline \multirow{7}{*}{ 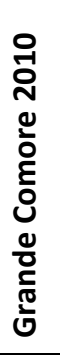 } & Male & 14 & 5 & 27 & 11 & 6 & 17 & 80 & \multirow{12}{*}{ 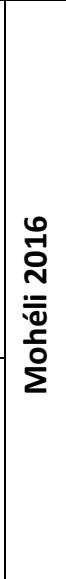 } & Sambia East & 12 & 3 & 20 & 8 & 11 & 12 & 66 \\
\hline & Chomoni & 16 & 4 & 25 & 15 & 4 & 13 & 77 & & Damu & 11 & 4 & 19 & 13 & 6 & 12 & 65 \\
\hline & Mtsamdou & 17 & 4 & 14 & 12 & 10 & 13 & 70 & & Sambia West & 12 & 3 & 16 & 11 & 9 & 12 & 63 \\
\hline & Chindini & 16 & 4 & 19 & 12 & 8 & 10 & 69 & & Bahausi* & 11 & 5 & 14 & 9 & 6 & 12 & 57 \\
\hline & Mwadzaza & 9 & 3 & 17 & 12 & 7 & 15 & 63 & & Mereni* & 10 & 4 & 23 & 9 & 4 & 6 & 56 \\
\hline & Itsandra & 9 & 3 & 21 & 10 & 1 & 13 & 57 & & Mea* & 12 & 3 & 13 & 8 & 7 & 11 & 54 \\
\hline & Island total & 30 & 7 & 43 & 19 & 12 & 23 & 134 & & Itsamia & 4 & 4 & 18 & 10 & 5 & 7 & 48 \\
\hline \multirow{5}{*}{ 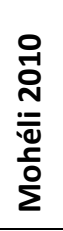 } & Bahausi* & 12 & 1 & 20 & 6 & 7 & 11 & 57 & & Ferenga* & 7 & 3 & 15 & 8 & 5 & 9 & 47 \\
\hline & Mea* & 16 & 2 & 17 & 5 & 4 & 10 & 54 & & Nioumachoua & 16 & 2 & 12 & 7 & 3 & 6 & 46 \\
\hline & Mereni* & 11 & 4 & 9 & 11 & 8 & 7 & 50 & & Bwanaidi & 12 & 2 & 14 & 4 & 6 & 8 & 46 \\
\hline & Ferenga* & 4 & 4 & 18 & 7 & 8 & 8 & 49 & & Island total & 23 & 7 & 39 & 19 & 16 & 21 & 125 \\
\hline & Island total & 22 & 5 & 34 & 12 & 12 & 18 & 103 & & & & & & & & & \\
\hline
\end{tabular}


5 Table 5. Vulnerability to bleaching of reef sites in the Parc National Mohéli, 6 displaying bleaching exposure, sensitivity and recovery scores for each site.

7 Scores are colour coded from light grey (best) to black (worst).

\begin{tabular}{|l|r|r|r|r|r|r|}
\hline Site & $\begin{array}{l}\text { Exposure } \\
\text { Score (E) }\end{array}$ & $\begin{array}{l}\text { Sensitivity } \\
\text { Score (S) }\end{array}$ & $\begin{array}{l}\text { Impact } \\
\left(E^{*} S\right)\end{array}$ & $\begin{array}{l}\text { Recovery } \\
\text { Score (R) }\end{array}$ & $\begin{array}{l}\text { Vulnerability to } \\
\text { bleaching } \\
(\boldsymbol{V})=(\boldsymbol{E})^{*}(\boldsymbol{S}) /(\boldsymbol{R})\end{array}$ \\
\hline Sambia West & 3.00 & 1.00 & 4.00 & 4.17 & 0.96 \\
\hline Damu & 3.50 & 1.00 & 4.50 & 4.17 & 1.08 \\
\hline Itsamia & 2.25 & 1.00 & 3.25 & 2.67 & 1.22 \\
\hline Sambia East & 2.50 & 1.00 & 3.50 & 2.50 & 1.40 \\
\hline Mereni & 3.50 & 2.00 & 5.50 & 3.50 & 1.57 \\
\hline Nioumachoua & 4.25 & 2.00 & 6.25 & 3.33 & 1.88 \\
\hline Bwanaidi & 3.00 & 3.00 & 6.00 & 3.33 & 1.80 \\
\hline Bahausi & 3.50 & 3.00 & 6.50 & 3.67 & 1.77 \\
\hline Ferenga & 2.25 & 5.00 & 7.25 & 3.17 & 2.29 \\
\hline Mea & 2.75 & 5.00 & 7.75 & 2.17 & 3.58 \\
\hline
\end{tabular}

Table 6. Exposure to human stressors and overall human impact by site. Scores 11 are colour coded from light grey (best) to black (worst).

\begin{tabular}{|l|c|c|c|c|c|}
\hline Site & $\begin{array}{l}\text { River } \\
\text { Pollution }\end{array}$ & $\begin{array}{l}\text { Fishing } \\
\text { Pressure }\end{array}$ & $\begin{array}{l}\text { Terrestrial } \\
\text { Erosion }\end{array}$ & Human Impact \\
\hline Bwanaidi & 1.4 & 1.67 & 0.2 & $\mathbf{1 . 0 9}$ \\
\hline Ferenga & 1.65 & 1.69 & 0.13 & $\mathbf{1 . 1 6}$ \\
\hline Mereni & 0.75 & 2.25 & 0.63 & $\mathbf{1 . 2 1}$ \\
\hline Sambia East & 0.79 & 1.88 & 2.27 & $\mathbf{1 . 6 5}$ \\
\hline Bahausi & 2.67 & 2.47 & 0.23 & $\mathbf{1 . 7 9}$ \\
\hline Mea & 2.5 & 2.5 & 0.63 & $\mathbf{1 . 8 8}$ \\
\hline Sambia West & 1.06 & 1.01 & 3.57 & $\mathbf{1 . 8 8}$ \\
\hline Itsamia & 0.38 & 0.38 & 5 & & $\mathbf{1 . 9 2}$ \\
\hline Damu & 0.5 & 0.5 & 5 & & $\mathbf{2 . 0 0}$ \\
\hline Nioumachoua & 5.83 & 14 & 2.5 & $\mathbf{7 . 4 4}$ \\
\hline
\end{tabular}


18 Table 7. Comparison of reef condition indicators from other locations in the WIO 19 with survey year in parentheses. Where a range was presented in the original 20 report the median value is given. * = MPAs with no-take fisheries enforced.

\begin{tabular}{|c|c|c|c|c|c|}
\hline Location (year) & Reference & $\begin{array}{l}\text { Coral } \\
\text { Cover } \\
(\%)\end{array}$ & $\begin{array}{l}\text { Coral } \\
\text { Genus } \\
\text { Richness }\end{array}$ & $\begin{array}{l}\text { Piscivore \& } \\
\text { Omnivore } \\
\text { biomass } \\
\text { (kg per ha) }\end{array}$ & CFDI \\
\hline $\begin{array}{l}\text { Comoros - Grande Comore } \\
\text { (2010) }\end{array}$ & This study & 40 & 47 & 330 & 134 \\
\hline Comoros - Mohéli (2016) & This study & 34 & 55 & 350 & 125 \\
\hline $\begin{array}{l}\text { Mozambique - Cabo Delgado } \\
\text { (2015) }\end{array}$ & $\begin{array}{l}\text { Samoilys et al. } \\
2015^{\mathrm{a}}\end{array}$ & 35 & 58 & 255 & 167 \\
\hline $\begin{array}{l}\text { Madagascar - North-Eastern } \\
\text { Coast (2010) }\end{array}$ & $\begin{array}{l}\text { Obura et al. } \\
2011^{\mathrm{b}}\end{array}$ & 48 & 61 & 228 & 172 \\
\hline $\begin{array}{l}\text { Kenya } \\
\text { - Kisite* (2013) } \\
\text { - Mpunguti and Wasini (2013) } \\
\text { - Watamu* (2013) }\end{array}$ & $\begin{array}{l}\text { Cowburn } \\
2016^{c}\end{array}$ & $\begin{array}{c}33 \\
15 \\
9 \\
\end{array}$ & $\begin{array}{l}36 \\
32 \\
35\end{array}$ & $\begin{array}{l}941 \\
319 \\
534\end{array}$ & $\begin{array}{c}90 \\
80 \\
104\end{array}$ \\
\hline $\begin{array}{l}\text { Maldives - Rasdhoo Atoll } \\
\text { (2014) }\end{array}$ & $\begin{array}{l}\text { Cowburn } \\
2016^{c}\end{array}$ & 23 & 37 & 726 & 95 \\
\hline $\begin{array}{l}\text { lles Eparses* } \\
\text { - Glorieuses (2011) } \\
\text { - Juan de Nova (2013) } \\
\text { - Bassas de India (2011) } \\
\text { - Europa (2011) }\end{array}$ & $\begin{array}{l}\text { Chabanet et } \\
\text { al. } 2015\end{array}$ & $\begin{array}{l}29 \\
39 \\
48 \\
83\end{array}$ & 44 & $\begin{array}{c}659 \\
929 \\
1255 \\
1263\end{array}$ & $\begin{array}{c}144 \\
131 \\
96 \\
121\end{array}$ \\
\hline $\begin{array}{l}\text { Chagos, British Indian Ocean } \\
\text { Territory* (2014) }\end{array}$ & $\begin{array}{l}\text { Samoilys et al. } \\
\text { unpubl. }^{d}\end{array}$ & 33 & 39 & 1244 & 151 \\
\hline
\end{tabular}

a. Samoilys, M, Obura, D, Osuka K (2015) Marine biodiversity survey of coral reefs in Cabo Delgado in March 2015. CORDIO Report for Our Sea Our Life Project, 30pp.

b. Obura D., Giuseppe, C., Rabearisoa, A., Oliver, T. (2011) A rapid marine biodiversity assessment of the coral reefs of Northeast Madagascar. RAP Bulletin of Biological Assessment, Conservation International, USA, 102pp.

c. Cowburn B. (2016) Coral reefs and climate change in the Indian Ocean: A case study of Watamu Marine National Park and other Indian Ocean Locations. PhD Thesis, University of Oxford, UK, $287 \mathrm{pp}$.

d. Samoilys, MA, Roche, R, Koldewey, H, Turner J. (Unpublished) Patterns in reef fish assemblages: insights from the Chagos Archipelago. Plos One: in revision. 


\section{Supplementary tables}

35 Table S1. Name, survey year, coordinates and information about reef type for each site from Grande Comore and Mohéli. Reef geomorphologies: OceanExposed Fringing-Reefs (OEFRs), Inner-Sea Fringing Reefs (ISFRs) and Inner-Sea Patch Reefs (ISPRs) (Andréfouët et al. 2006). * indicates sites repeated in Mohéli in 2010 and 2016.

\begin{tabular}{|c|c|c|c|c|}
\hline & Site Name & Year & Coordinates & $\begin{array}{l}\text { Reef geomorphology, } \\
\text { depth and type }\end{array}$ \\
\hline \multirow{6}{*}{ 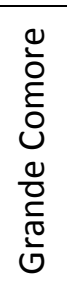 } & Itsandra & 2010 & $11.670 \mathrm{~S}, 43.264 \mathrm{E}$ & OEFR - 10m - Forereef \\
\hline & Mwadzaza & 2010 & $11.777 \mathrm{~S}, 43.241 \mathrm{E}$ & OEFR - 10m - Forereef \\
\hline & Chindini & 2010 & 11.936S, 43.486E & OEFR - 10m - Forereef \\
\hline & Male & 2010 & 11.896S, 43.527E & OEFR - 10m - Forereef \\
\hline & Chomoni & 2010 & 11.645S, 43.397E & OEFR - 10m - Forereef \\
\hline & Mtsamdou & 2010 & 11.610S, 43.394E & OEFR - 10m - Forereef \\
\hline \multirow{10}{*}{$\begin{array}{l}\frac{\overline{\bar{d}}}{\overline{\frac{1}{0}}} \\
\overline{0}\end{array}$} & Bahausi * & 2010,2016 & 12.398S, 43.698E & ISFR - 10m - Forereef \\
\hline & Ferenga * & 2010,2016 & $12.428 \mathrm{~S}, 43.696 \mathrm{E}$ & OEFR - $18 m$ - Deep terrace \\
\hline & Mea * & 2010,2016 & $12.382 \mathrm{~S}, 43.740 \mathrm{E}$ & ISFR - 10m - Forereef \\
\hline & Mereni * & 2010,2016 & 12.340S, 43.650E & OEFR - 10m - Forereef \\
\hline & Bwanaidi & 2016 & 12.406S, 43.715E & ISFR - 10m - Forereef \\
\hline & Damu & 2016 & $12.314 \mathrm{~S}, 43.631 \mathrm{E}$ & OEFR - 10m - Forereef \\
\hline & Itsamia & 2016 & $12.383 \mathrm{~S}, 43.875 \mathrm{E}$ & OEFR - 10m - Forereef \\
\hline & $\begin{array}{l}\text { Nioumachoua } \\
\text { (Flat) }\end{array}$ & 2016 & $12.370 \mathrm{~S}, 43.711 \mathrm{E}$ & $\begin{array}{l}\text { ISFR - 5m -Reef crest } \\
\text { ISFR - 1m -Reef flat }\end{array}$ \\
\hline & Sambia East & 2016 & 12.395S, 43.805E & ISPR - 10m - Forereef \\
\hline & Sambia West & 2016 & $12.386 \mathrm{~S}, 43.787 \mathrm{E}$ & ISPR - 10m - Forereef \\
\hline
\end{tabular}

41 
44 Table S2. Fish trophic groups used as indicators for assessing coral reef health and vulnerability to climate change (adapted from Green \& Bellwood 2009, Sandin \& Williams 2010, Samoilys and Randriamanantsoa 2011, Samoilys et al. unpubl.). Numbers in parentheses refer to trophic groups that were aggregated for presentation or analysis: $1=$ grazers \& detritivores, $2=$ non-browsing Scarinae (Fig.3); $1+2+3$ = herbivore-detritivore bleaching recovery index (Table 1).

\begin{tabular}{|c|c|c|c|}
\hline Functional Group & $\begin{array}{l}\text { Notes on feeding habits and } \\
\text { selection of species }\end{array}$ & Group/family & English name or species \\
\hline Grazers (1) & $\begin{array}{l}\text { Feed on algal turf and } \\
\text { sediment to extract detritus, } \\
\text { microbes and diatoms; may } \\
\text { limit growth of macroalgae }\end{array}$ & $\begin{array}{l}\text { Acanthuridae } \\
\text { Siganidae }\end{array}$ & $\begin{array}{l}\text { Zebrasoma spp. } \\
\text { A. nigrofuscus, other } \\
\text { Acanthurus spp. e.g, } A \text {. } \\
\text { lineatus } \\
\text { rabbitfish }\end{array}$ \\
\hline $\begin{array}{l}\text { Grazer-detritivores } \\
\text { (1) }\end{array}$ & $\begin{array}{l}\text { Feed on algal turf and } \\
\text { sediment to extract detritus, } \\
\text { microbes and diatoms; may } \\
\text { limit growth of macroalgae }\end{array}$ & $\begin{array}{l}\text { Acanthuridae } \\
\text { Pomacanthidae }\end{array}$ & $\begin{array}{l}\text { A. blochii, A. dussumieri, } A \text {. } \\
\text { leucocheilus, } \\
\text { A. nigricauda, A. } \\
\text { xanthopterus, A. tennenti } \\
\text { Centropyge spp.. }\end{array}$ \\
\hline Detritivores (1) & $\begin{array}{l}\text { Strictly detritivorous - feed } \\
\text { on organic matter in } \\
\text { sediment and reef surfaces }\end{array}$ & Acanthuridae & Ctenochaetus spp. \\
\hline Corallivores & $\begin{array}{l}\text { Obligate and facultative } \\
\text { corallivores are a secondary } \\
\text { indicator of coral } \\
\text { community health. }\end{array}$ & Chaetodontidae & $\begin{array}{l}8 \text { Butterflyfish: C. bennetti, } \\
\text { C. lineolatus, C. } \\
\text { melannotus, } \\
\text { C. meyeri, C. ornatissimus, } \\
\text { C. trifascialis, C. } \\
\text { trifasciatus, } \\
\text { C. zanzibarensis }\end{array}$ \\
\hline Large excavators (2) & $\begin{array}{l}\text { Take few, large, deep bites, } \\
\text { and remove calcareous } \\
\text { substratum; play a large role } \\
\text { in bioerosion }\end{array}$ & Scarinae & $\begin{array}{l}\text { Chlorurus spp. }>35 \mathrm{~cm} \text {, e.g. } \\
\text { C. strongylocephalos } \\
\text { Cetoscarus ocellatus } \\
\text { \{Bolbometapon } \\
\text { muricatum\} }\end{array}$ \\
\hline Small excavators (2) & $\begin{array}{l}\text { Remove algae and } \\
\text { substrate; play a smaller } \\
\text { role in bioerosion }\end{array}$ & Scarinae & Chlorurus spp. $<35 \mathrm{~cm}$ \\
\hline Scrapers (2) & $\begin{array}{l}\text { Remove algae, sediment } \\
\text { and detritus by closely } \\
\text { cropping or scraping the } \\
\text { substrate }\end{array}$ & Scarinae & $\begin{array}{l}\text { Scarus spp., Hipposcarus } \\
\text { spp. }\end{array}$ \\
\hline \multirow[t]{4}{*}{ Browsers (3) } & \multirow[t]{4}{*}{ Feed on large macroalgae } & Scarinae & $\begin{array}{l}\text { Calotomus spp. } \\
\text { Leptoscarus spp. }\end{array}$ \\
\hline & & Acanthuridae & $\begin{array}{l}\text { Naso spp. }<21 \mathrm{~cm} \text { Naso } \\
\text { unicornis, N. tuberosus, N. } \\
\text { elegans }\end{array}$ \\
\hline & & Ephippidae & Bat fish - Platax spp. \\
\hline & & Kyphosidae & $\begin{array}{l}\text { Rudder fish - Kyphosus } \\
\text { spp. }\end{array}$ \\
\hline Piscivores & $\begin{array}{l}\text { Top level predators, exert } \\
\text { top-down control on lower } \\
\text { trophic levels of fish, } \\
\text { vulnerable to overfishing, }\end{array}$ & $\begin{array}{l}\text { Epinephelidae } \\
\text { Lutjanidae }\end{array}$ & $\begin{array}{l}\text { All groupers } \\
\text { Aprion viriscens } \\
\text { Lutjanus bohar }\end{array}$ \\
\hline
\end{tabular}




\begin{tabular}{|l|l|l|l|}
\hline & good indicators of fishing & & \\
\hline Omnivores & $\begin{array}{l}\text { Second-level predators with } \\
\text { mixed diets: small fish, } \\
\text { invertebrates, dead animals. } \\
\text { Their abundance a good } \\
\text { indicator of fishing pressure }\end{array}$ & $\begin{array}{l}\text { Haemulidae } \\
\text { Lethrinidae } \\
\text { Lutjanidae }\end{array}$ & $\begin{array}{l}\text { All sweetlip } \\
\text { All emperor } \\
\text { All snapper except Aprion } \\
\text { viriscens \& Lutjanus bohar }\end{array}$ \\
\hline
\end{tabular}

51

Additional References

52

53

54

55

56

57

Sandin S, Williams I. (2010) Trophic classification of reef fishes from the Tropical U.S. Pacific (Version 1.0). Series: Scripps Institution of Oceanography Report. San Diego, California. 19pp. 